OPEN ACCESS

Edited by:

Tom Brughmans,

University of Konstanz, Germany

Reviewed by:

Thomas G. Whitley,

Sonoma State University, USA

Devi Taelman,

Ghent University, Belgium

Benjamin R. Jennings,

University of Bradford, UK

${ }^{*}$ Correspondence:

Clara Filet

clara.filet@gmail.com

Specialty section:

This article was submitted to

Digital Archaeology,

a section of the journal

Frontiers in Digital Humanities

Received: 17 September 2016

Accepted: 09 January 2017

Published: 01 February 2017

Citation:

Feugnet A, Rossi F and Filet C (2017) Co-presence Analysis and Economic

Patterns: Mediterranean Imports in the Celtic World.

Front. Digit. Humanit. 4:1. doi: 10.3389/fdigh.2017.00001

\section{Co-presence Analysis and Economic Patterns: Mediterranean Imports in the Celtic World}

\author{
Aurélia Feugnet ${ }^{1,2}$, Fabrice Rossi ${ }^{3}$ and Clara Filet ${ }^{1,2,3 *}$ \\ 'UMR 7041 ArScAn 'Archéologies Environnementales', University Paris 1, Paris, France, '2 UMR 8546 AOROC 'Celtes et \\ Etrusques', University Paris 1, Paris, France, ${ }^{3}$ EA 4543 'SAMM', University Paris 1, Paris, France
}

This article presents one of the first steps of a project that aims at exploring the diffusion patterns of Mediterranean imported goods in Late Iron Age Europe (250-25 BC) and the organization of the commercial interactions of these goods. It brings together two archeologists and a mathematician in the study of a large inventory of 57,735 Italian and Greek imports discovered from England to Serbia. This large amount of new and unpublished data is analyzed through the joint use of network analysis tools and formal statistical methods. The analysis focuses on detecting patterns in the association of imported artifacts that are often found on the same sites. The objectives are to highlight groups of imports that may have circulated together and to emphasize regional selections by local populations. At this stage of the study, two main systems of imports have been highlighted used, respectively, in West and Central Europe. Interesting leads that will need further investigation include the imports status and the role they played in Celtic societies, as acculturated objects or more as objects for acculturation.

Keywords: co-presence analysis, Mediterranean imports, La Tène period, two-mode network, ancient trade, cultural contacts

\section{INTRODUCTION}

The introduction of Mediterranean imports to Latenian Europe is definitely one of the most important phenomena of cross-cultural interactions during the late Iron Age. During the last three centuries BC, hundreds of thousands of goods were produced in the Italian and Greek peninsulas and spread across most of the continent to be exchanged (Picon and Ricq de Boüard, 1989). This major trade network is now well documented by archeological discoveries.

This article focuses on the diffusion and reception of Roman and Greek imports identified from southern England to Serbia dating between 250 and 25 BC. The aim is to detect groups of exogenous artifacts that are recurrently found together, because they were conjointly spread and sold, or because they corresponded to selective choice patterns operating in particular regions and sites. This analysis stands as an important step in the study of a large inventory of Mediterranean imports in Latenian Europe, which provides new elements for the understanding of the supply networks and their evolution through time and space. This step is based on the use of co-presence matrices to highlight the patterns of artifacts associations. The significance of those recurrent associations is evaluated via a specific statistical score. 
These matrices provide a valuable example of how network formalization of non-relational data can become a tool in the study of a large database filled with heterogeneous archeological data. The analysis is first developed at the European scale, to emphasize the main features from ancient (third century BC) to Recent Horizon (first century BC). The second section focuses on comparisons between five selected regions across Europe, to better perceive regional specificities in the way Latenian populations imported and consumed the luxury products from faraway lands.

\section{HISTORICAL BACKGROUND}

The study concerns the second half of the La Tène Period (LT C and $\mathrm{D}$, between 250 and $25 \mathrm{BC}$ ). The third century BC marks the maximal expansion of the Celtic World, from the British Islands to the center of Turkey.

During this time interval, the climate was temperate, even hot and dry. There was no longer climatic deterioration, which could have unsettled agro-pastoral populations and slowed down trade connections.

From the beginning of the third century, the entire Celtic World underwent deep transformations, including important innovations. Indeed, at their maximum expansion, the Celtic societies integrated Greek coins (Gruel, 1989). Simultaneously, the development of iron tools helped to provide a more efficient and extensive agriculture. For the first time, the new ability to cultivate heavy soils allowed Celtic populations to settle in the whole landscape (Matterne, 2001; Malrain et al., 2002). New kinds of sites stand for the complexification of Celtic societies such as oppida, big urbanized and fortified cities (Collis, 1984; Fichtl, 2000), and sanctuaries (Arcelin and Brunaux, 2003). Those sites were the symbols of a new hierarchy and landed elite, which was firmly rooted in the landscape.

All these internal innovations and developments went along with the multiplication of the introduction of imported objects from the Mediterranean States. The phenomenon started with amphorae and ceramic vessels (Poux, 2004), but the number of imported categories rapidly rose. In the first-century BC, European populations imported a large amount but also a wide variety of Mediterranean goods. The greater part of these imports came from the Italic peninsula, going along the major communication axis "Rhône-Saône-Seine" rivers.

Thus, in two centuries, Celtic societies were deeply transformed until they adopted political systems nearly close to archaic states (Brun, 1993, in press). The social acknowledgment of the aristocracy was now based on the achievement of land exploitations. Also, this fixation of the elites in the landscape helped with the setting up of exchange networks, at a large scale.

\section{ISSUES}

In protohistoric studies, we can only rely on archeological facts. In our case, we have to deal with the discoveries of imported objects, and not so much more, to understand at least a part of the economical networks of the La Tène period. We need to closely study these imports to be able to merely picture the cargoes, the distribution networks, the trade patterns or even the actors involved in the transport, delivery, and use.

The project aims at exploring the diffusion patterns of Mediterranean imported goods in Latenian Europe and the organization of the commercial interactions of those goods. Trade modalities should be first examined through preferential associations of artifacts that may have spread together or/and reflect selective choices of the local buyers. Can we recognize standard cargoes or specific orders? Can we perceive differences in the choice of artifact sets between regions? The same question should be raised about the types of sites. Do those imports associations reflect functional or hierarchical distinctions? The general assumption would state that the longer a site belongs to the highest status, the more important and diverse its amount of imports would be. However, some regions are already known for having a specific use of certain imports that are dedicated to funerary contexts (Metzler et al., 1991). Can we highlight organization patterns that distinguish types of sites that possess specific assemblages of artifacts? We hope that this kind of analysis will provide new materials to better understand the organization of Mediterranean imports trade and the different roles of the settlements in the diffusion of those products.

Finally, all these issues have to be investigated from a chronological point of view. Are all those patterns perennial from one period to another or can we perceive evolving practices? Time is one of the main factors to understand the imports phenomenon, the introduction rhythms of these productions, and their integrations in Celtic societies.

This article will mostly focus on identifying those specific selections and regional particularisms and see how they seem to evolve through time.

Studies about artifacts associations are not new in archeology (e.g., Nakoinz, 2013), but have so far focused on objects that were produced and circulated inside the area under study. In these cases, the diversity of associations mostly relies on differences in material culture, which could be interpreted in cultural specificities. Those differences can possess a relative geographic homogeneity and help to highlight cultural borders. In this study, however, all the objects that are taken into account were produced outside of our area of interest. All of them are imports from distant regions. Thus, each of our archeological sites has a priori the same chance to contain each of our objects. Here, the diversity of assemblages cannot derive from the material culture. It can imply cultural choices and selections, but would also highlight more clearly the richness of the site and its inclusion inside the exchange networks.

\section{CORPUS}

The geographical frame includes 14 countries from western and central continental Europe (Figure 1).

All the data used in this study are primarily from the $\mathrm{PhD}$ thesis of Aurélia Feugnet. It consists of a large inventory of Mediterranean imports discovered on archeological sites that are situated inside the study area and dating from the third to the first century BC. Data were systematically collected from published datasets, regional inventories, and already existing databases. 


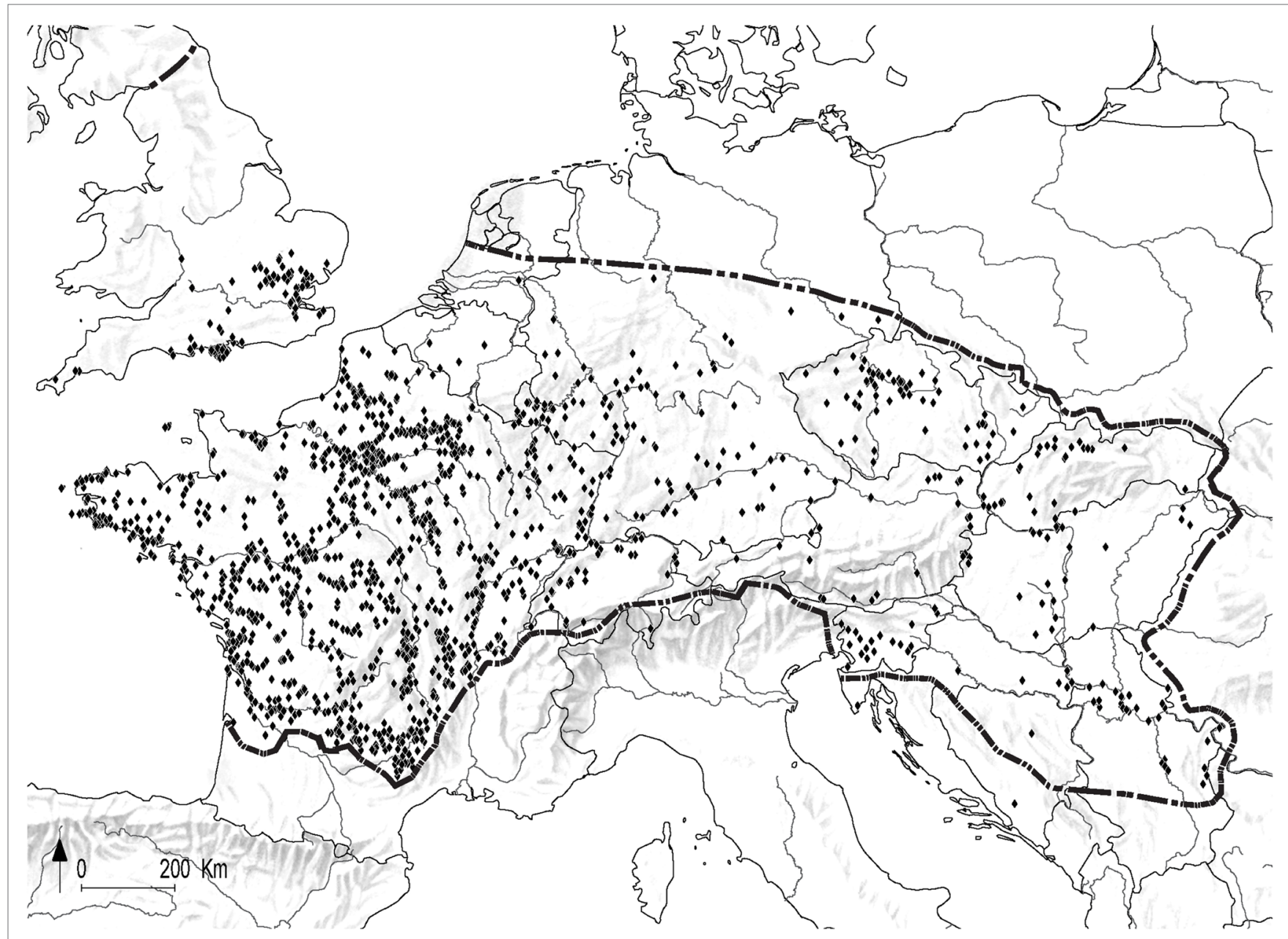

FIGURE 1 | Distribution map of the studied sites.

The final inventory gathers 1,885 sites and 1,914 occupations (or phases), and 57,735 objects which are counted in Minimum Number of Individuals, which estimates the minimum corresponding number of wares from the discovered sherds (Husi, 2001). This corpus is yet not published.

\section{The Imports}

In this study, imports are the Greek and Romans items that have crossed the cultural frontiers and have finally been discovered in Celtic contexts, after being used by Celtic populations. This varied corpus of artifacts is divided into 10 groups of imported objects: amphorae, ceramic vessels, metal vessels, weapons, Greek coins, medical and writing instrumentum, pieces of jewelry, Greek alphabet, glass vessels, and art objects. They generally belong to the economic sphere. However, in some cases, their status can be a little bit hybrid, as coins and weapons. About coins, the current hypothesis is that they probably reached the Celtic world in the form of payment (against services as mercenary activities), but this assumption recently tends to be denied (Baray, 2014). About weapons, the situation is vaguer, and their presence can be the result of many forms of contacts (the most widespread hypothesis are gift exchanges, diplomatic ties, or war booty). When possible weapons used by Romans during the Gallic conquest were excluded from the data.

The typology used to study the material as two levels:

- a coarse level with 10 categories (e.g., amphorae);

- a fine level with 50 types (e.g., Italic or Iberian amphorae).

All the finds were quantified by the MNI. The majority of the 57,735 objects belongs to the amphorae group (54,334 individuals). It should be noted, however, that 24,000 of them were discovered on the single site of Chalon-sur-Saône (Saône-et-Loire). All of them belong to the same type Dressel 1 and are dated from the period 3 to 4 of the port area, between 150 and 50 BC.

\section{The Sites}

The majority of sites belongs to settlements $(1,046)$. Two Hundred Forty-five of them are funerary sites, 101 are places of worship, 205 belong to other types of sites (caves, salt workshops, wrecks, etc.), and 317 are of unspecified function. 
The frame used for this project is deliberately defined as geographically vast and chronologically determined to reflect the whole Mediterranean imports phenomenon of the La Tène period. It should be pointed out, however, that this corpus is far from exhaustive. It was only built from the published data, in a large area where the state of the research highly differs from one region to another. ${ }^{1}$ Nevertheless, we assume that its considerable size already contains some structures that could partly reflect the specific features of the imports distribution in La Tène Times.

The biggest difficulty remains in how to deal with the main opposition between sites that mainly structure the inventory: the enormous amount of amphorae in the western area and its near-total absence in central Europe. As amphorae are the major component of imports in half of the regions and as their presence seems to be structurally essential to understand commercial patterns, it was decided to keep them in the study. The analysis will need, however, to look beyond this major pattern to perceive less obvious traits and schemes.

\section{The Chronology}

Working on the Iron Age period needs to deal with several regional chronologies that are highly difficult to homogenize at the European scale (Barral, 2012; Pierrevelcin, 2012). Some Mediterranean imports had a lengthy production lifetime, and we do not know how long they could have circulated on the way to where they were found. On the other hand, numerous sites were occupied during a long period of time and others extended over one generation only, and it is not possible to assess the dating on which each import arrived and was consumed. As a consequence, it is not possible to work with precise chronological steps.

Considering this problem, we decided to keep only the sites with a rather short occupation time, defined inside three chronological horizons (Ancient Horizon, Middle Horizon, and Recent Horizon; Figure 2). Those horizons correspond to three intervals of time in which the sites taken into account were occupied. It means that a site cannot appear on two chronological intervals/ horizons. Sites that were occupied for a longer period, or whose occupation overlapped two horizons, were gathered in a fourth non-dating horizon. This latter has been equally studied as the three others, but its results will not be presented here. Finally, the Ancient Horizon concerns only 503 objects for 43 occupations: the co-presences observed on this horizon are to uncommon to support the type of analysis proposed here. Therefore, this article focuses on the Middle and Recent Horizons.

\section{METHODOLOGY}

\section{Formalizing Data: Thinking Networks}

In most disciplines, networks tools are mobilized to study proper relational systems, constructed from physical or social relationships. In that case, networks are given, traceable, and can be directly analyzed. However, these kinds of data are rather rare in

${ }^{1}$ We could also add that the data collection is dependent on the country where they come from and on the archaeological employed research methods (rescue archaeology, archaeological surveys, and quality of the data publications).

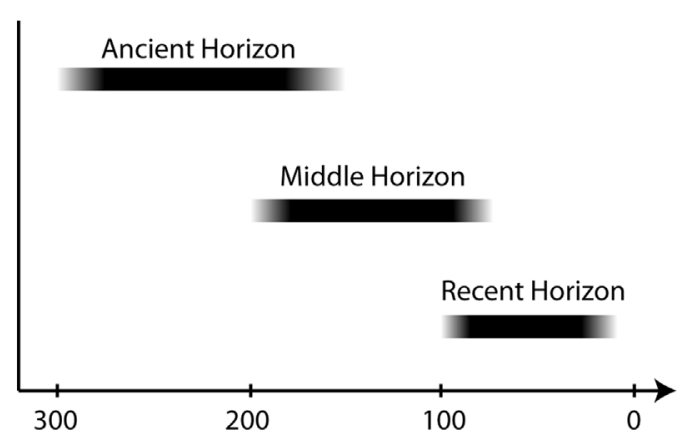

FIGURE 2 | Definition of the three chronological horizons used for the study

archeology except roads and intervisibility networks (Graham, 2006; Čučković, 2015). But those methods can also be used as analysis tools and applied to non-relational archeological data. The input data table is extracted from the database into a simple table, where the individuals (the sites) are laid out in rows and the attributes (the artifacts) in columns (Figure 3A). Each cell gives the number of object of type "n" discovered in site "s."

A network can be constructed from such a table as follows. Each object is represented by a node of the network. Similarly, each site is represented by a node. Finally, the discovery of an object in a site is represented by a link between the corresponding nodes of network (Figure 3B; Mercklé, 2004; Brughmans, 2010). This construction leads to a so-called 2-mode network: links exist only between nodes of the two different categories (in other words, there are direct links neither between nodes associated to sites nor between nodes associated to objects). It can then be projected in two networks of only one category:

- a 1-mode network of sites that links the sites that possess the same artifact (Figure 3C);

- a 1-mode network of objects that links the artifacts that are co-present on the same sites (Figure 3D).

In the both cases, a weight can be added on the link between two nodes. In the object network, the link weights stand for the numbers of sites on which each pair of artifacts is co-present. This objects network enables us to highlight similarities in the distribution of some artifacts. It helps to emphasize the ones that are frequently found together. In the second case, the weight indicates the number of common objects discovered on two sites. This sites network brings out sites that look alike in the artifacts they contain. It is then possible to work in a geographical space; for example, to examine whether the similarities of blends can be partly explained by geographical proximities.

Those two network types are just a new formalization of a data table (Rossi et al., 2014). This network view gives access to a large set of network-specific tools designed to detect underlying structures in the data (Brughmans, 2010). Notice, however, that classical statistical methods (e.g., hierarchical clustering or multiple correspondence analysis) could also be applied to the original data. 


\section{A}

\begin{tabular}{|l|r|r|r|r|} 
& Object 1 & Object 2 & Object 3 & Object 4 \\
\hline Site A & 1 & 1 & 0 & 0 \\
\hline Site B & 1 & 1 & 0 & 0 \\
\hline Site C & 0 & 0 & 1 & 0 \\
\hline Site D & 0 & 0 & 1 & 1 \\
\hline Site E & 0 & 1 & 1 & 1 \\
\hline Site F & 0 & 0 & 1 & 1 \\
\hline
\end{tabular}
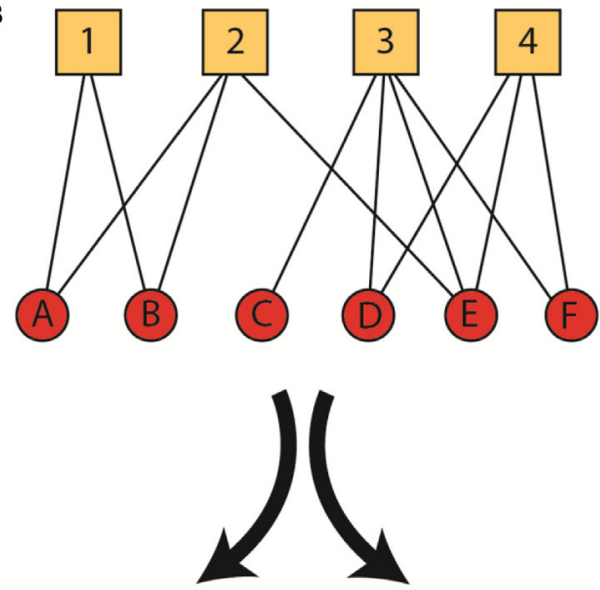

C

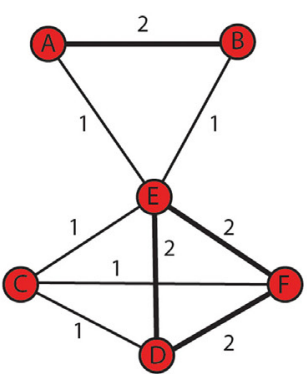

D

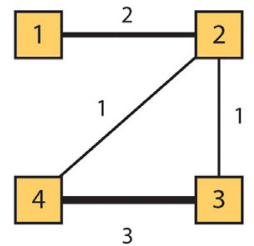

FIGURE 3 | From the archeological database to its formalization through networks. (A) Simple contigency table of archaeological finds. (B) Its visualisation through a 2-mode network. (C) The projection of the 2-mode network into a 1-mode network of sites linking the sites that possess the same artifact. (D) The projection of the 2-mode network into a 1-mode network of objects linking the artifacts that are co-present on the same sites.

\section{Co-presence Matrices}

As every network, the two presented above can be visualized in different ways. The most common is a node-link diagram in which each node is represented by a disk and each link by a segment. The same network can also be represented by a symmetrical matrix (Bertin, 1967), with the same list of entities in rows and columns (Figure 4). In an object network, each cell contains the number of sites on which the two artifacts in the row and column are co-present. In a sites network, it shows the number of objects shared by the two sites indicated in row and column.

\begin{tabular}{|l|c|c|c|c|}
\cline { 2 - 5 } \multicolumn{1}{c|}{} & Object 1 & Object 2 & Object 3 & Object 4 \\
\hline Object 1 & 0 & 2 & 0 & 0 \\
\hline Object 2 & 2 & 0 & 1 & 1 \\
\hline Object 3 & 0 & 1 & 0 & 3 \\
\hline Object 4 & 0 & 1 & 3 & 0 \\
\hline
\end{tabular}

FIGURE 4 | Example of a simple co-presence matrix of objects

Node-link diagrams can be useful, especially for small networks, i.e., with less than 100 nodes. However, it swiftly becomes illegible when handling a lot of data and complex structures, contrarily to matrix-based representations (Ghoniem et al., 2005). Another bias can easily occur in the interpretation, when unaware readers tend to understand the ties in the graph as a proper relationship between the actors. An even worse problem is the natural tendencies of viewers to interpret the length of a link in the node-link diagram as a dissimilarity between the linked nodes, while this length is only a by-product of the layout algorithm (Fabrikant et al., 2004). When the data under study are proper relational data, those tendencies, especially the latter one, can lead to misinterpretations. In our context, while the object distribution similarity between two sites can say something about cultural closeness and unity, it is pointless to directly interpret it as a straight social link between them. In addition, viewers have also a tendency to follow series of links as a road, leading to increase in risks of misinterpretations (Fabrikant et al., 2004). The risk of those misinterpretations is far less pronounced when using a matrix representation. In addition, the matrix representation is valuable for comparison. It allows us to directly highlight the main features and their contrast with other matrices.

However, matrix representations are not without specific issues. In particular, it is well known that the order in which the entities are represented has a strong influence on the legibility of the matrices (Bertin, 1967; Henry and Fekete, 2006). This is mitigated in the present context by natural orderings for both objects (by categories) and sites (via geographical considerations).

It should also be pointed out that co-presence matrices of variables have already existed in statistics for a long time (Djindjan, 1991) and are not always linked with network theory and methods legibility of the matrices. Some archeological studies have employed them on their own to help to construct typologies from traits associations (Tugby, 1958; Clarke, 1962). They can also be used as tools for restructuring the variables of a dataset.

Nevertheless, numerous benefits can be gained from adopting a network point of view on co-presence matrices. The original 2 -mode network emphasize the strong links between object and site points of view. This allows us switching from one point of view to the other to complement an analysis, for instance by 
listing the sites that contribute to the co-presence of two objects. The network view also gives access to a large selection of tools, from visualization techniques to automatic structure analysis (e.g., Block-modeling).

Several studies are already based on the artifacts co-presence to highlight similarities and proximities between sites (Sindbaek, 2007a,b, 2012, 2013; Brughmans, 2010; Östborn and Gerding, 2014, 2015; Jennings, 2016). However, even if the two perspectives are highly dependent on each other, only a few studies have been interested in the co-occurrences of objects in themselves.

Most of them are based on 2-mode networks linking sites to objects or attributes, which are translated onto a network of sites, linked by the fact that they possess at least $n$ objects/attributes in common. The sites point of view is often preferred because most of those works focus on spatial problematics (urbanization, diffusion, and migration), for which it is more informative to represent the network in space. In our case, both perspectives (network of sites and objects) are meaningful and offer different points of view on the system of Mediterranean trade in Latenian Europe. In this article, we choose to focus on the artifacts networks and object associations. Co-presence matrices will help to highlight groups of artifacts that are systematically (or never) found together and to compare those associations and oppositions from one period and one region to another. We aim to provide a fresh look on an already widely studied phenomenon, the complex functioning of which, however, is still poorly understood.

\section{Adding the Significance}

As explained earlier, the co-presence matrix corresponds to a symmetrical matrix with the same list of artifacts in rows and columns. Each cell contains an indication of the number of sites on which both the corresponding imports in row and column were discovered. A classical way to represent this number of sites is to use a gray scale to color the cells (high numbers use dark tones, see Figures $\mathbf{6}$ and $\mathbf{7}$ for an example).

However, this can be highly misleading as the number of co-presence depends strongly on the number of presences. For instance, objects that are found on numerous sites will naturally be co-present on more sites than rare objects while this might not be a statistically sound proof of a clear and voluntary association. For example, we would expect to observe that Italic amphorae and Campana ceramics are often discovered together, because both are the most numerous imports in Western Europe. In a simple gray scale representation, we expect the visualization to be dominated by such possibly spurious associations. Notice that while the problem manifests in the visualization, its roots are in the raw co-presence numbers and not a consequence of the visualization itself.

To avoid this problem, the co-presences should be related to the importance of the diffusion of each object and to the variety of objects at each site. The idea is to compare the observed associations (that is the observed co-presence numbers) to expected co-presences that could be observed if the objects were associated to sites at random, while preserving site diversities and object popularity. The differences between the actual co-presences and the expected ones are represented via color coding. A gray cell corresponds to non-significant co-presences. When the number of sites where the objects are co-present is significantly high, the corresponding cells are colored in red. When this number of sites is significantly low, cells are colored in blue.

Interpreting non-significant co-presences is difficult. By construction of the significance score, those co-presences could be caused by chance, that is by a random association of artifacts to sites. Thus, the data support neither a tendency to group the artifacts nor a tendency to avoid grouping them during import. If other evidences tend to support co-import (or avoidance of such), non-significant co-presences do not invalidate them. On the contrary, this is more a call for collecting more data to assess the significance score with more precision. Details on the method are given in Appendix.

The list of artifacts studied in each matrix corresponds to the list of objects that were discovered in the whole of Europe at the same period. White rows (and columns) correspond to objects that are not present in this region, but were found in another region at the same period.

It should be noted that the expected number of sites of copresence are computed at the regional level to take into account differences between regions in terms of number of sites and site diversities. This enables to compare directly matrices one to another, disregarding regional specificities (such as having a large number of sites compared to another region). In particular, selection effects at the artifact level should appear clearly when comparing a region to Europe (or to another region).

Finally, we have to point out that this kind of matrix is never used and studied on its own, but it is always examined in connection with the database to make the counts and the contexts of discovery more precise.

\section{RESULTS}

We carried the analyzes in two steps: first, we made matrices at the European scale, to be able to observe the entire phenomenon, and second, we created five macro regions to zoom on strategic areas, to better understand regional effects and the complexity of the economic structures.

\section{European Scale}

The following table presents the number of occupations and objects for each horizon. One immediately notices a high densification and diversification of the imports from one horizon to another, owing to the increase in the amount of data (Figure 5).

As suggested earlier, the Ancient Horizon is not taken into account in this analysis.

\section{Middle Horizon: 261 Occupations, 13,769 Objects (Including 13,280 Amphorae)}

The Middle Horizon exemplifies this diversification with the appearance of several new types of imports, as the Greek Alphabet and the Roman weapons. As 8 of the 10 categories are now present in the database, the co-presence analysis starts to demonstrate its usefulness.

The basic visualization of the co-presence matrix indicates that most of the coins are discovered alone and seems to never appear on the same occupation than other Mediterranean imports 


\begin{tabular}{|l|c|c|c|c|}
\hline $\begin{array}{l}\text { Co-presences } \\
\text { matrices }\end{array}$ & $\begin{array}{c}\text { Number of } \\
\text { occupations }\end{array}$ & $\begin{array}{c}\text { Number of } \\
\text { objects (NMI) }\end{array}$ & $\begin{array}{c}\text { Number of } \\
\text { categories /10 }\end{array}$ & $\begin{array}{c}\text { Number of types } \\
\mathbf{5 0}\end{array}$ \\
\hline Ancient Horizon & 43 & 503 & 8 & 18 \\
\hline Middle Horizon & 261 & 13769 & 8 & 35 \\
\hline Recent Horizon & 1009 & 39298 & 10 & 43 \\
\hline
\end{tabular}

FIGURE 5 | Data statistics per horizon at European scale.

(Figure 6). One may wonder whether Greek coins imported in the Celtic world were systematically not associated with the other kinds of material, or if it is just a problem of ancient discoveries and a lack of contextual knowledge. The small number of individuals and sites does not allow us to decide. The main association concerns the Italic amphorae (6006), the Campana ceramic (6010), and the strainers (6041). Those objects appear to be the most associated imports discovered on our sites. However, they are also the most common. Would their high number be sufficient to explain why they are discovered together so often?

This significance matrix (Figure 6) helps us balance this general overview of observed co-presence and emphasize the most significant ones. It sometimes partly downplays the importance of some associations. For example, weapons seemed to be often associated with several other categories. However, weapons are very rare in the Middle Horizon blends (on 3 sites only and for a total of 28 objects). But these three sites are major import centers, which explain the numerous co-presences for the weapons category with almost all the other groups in the simple co-presence matrix. The weapons disappear in the significance matrix. The same problem can be raised concerning the pieces of jewelry. This means that the observed co-presences are not significantly different from what could be observed if weapons and jewelry, for instance, were allocated independently at random to the sites. In other words, the observed co-presences could have happened by chance and not as a consequence of a deliberate association. Here, there is no reason to believe that weapons are particularly associated with the instrumentum and the pieces of jewelry. This example demonstrates the relevance of such visualization.

The matrix also emphasizes the significant trends (in dark red and dark blue). Most of them relates to intracategory co-presences, which are represented in the diagonal of the matrix. This is the case for the ceramic vessel, the instrumentum, the coins, and the metallic vessel, some type of which are significantly associated to other types of the same category. It is, for example, interesting to point out that Ampurian pottery $(6,008)$ and Campana ceramics $(6,010)$ are significantly discovered together, even if they are not produced in the same part of the Mediterranean. Concerning the Amphorae, the co-presence between the Italic types $(6,006)$ and the undetermined ones $(6,004)$ appears in dark blue. This opposition can be easily explained by the precision and the quality of ceramic studies for each site. In one site, the amphorae can be identified or not, but are rarely partly characterized.

Finally, three types of imports stand out in possessing intercategory trends. Even if the Italic amphorae and the Campana are both highly distributed (12,648 Italic amphorae and 211 Campana ceramic), they seem to be significantly more associated comparing to what could be expected by chance. The same remark works for the strainers $(6041 ; \mathrm{MNI}=30)$, to a slightly lesser extent.

To summarize the main results for this horizon, the significance matrix underlies a major combination of three imports (Italic amphorae, Campana ceramics, and strainers), which are all highly distributed but significantly associated together. Most of the other clear co-presences concerns some imports of the same categories (Ampurian and Campana ceramics, medical and hygiene instrumentum).

\section{Recent Horizon: 1,009 Occupations, 39,298 Objects (Including 37,587 Amphorae)}

During the Recent Horizon, and for the first time, all categories of imports are present. According to the numbers of discovered imports, we can start by saying that this horizon is the most decisive in the Mediterranean imports phenomenon (Figure 7). This densification reaches a quantitative step for which statistical analysis become particularly relevant. As many co-presences are achieved, significant trends are now numerous. As seen with the previous horizon, three categories stand out in the first matrix: amphorae, ceramics, and metal vessels. It specifically concerns the Italic amphorae (6006), the Campana ceramics (6010), and metal vessels, in particular strainers (6041) and patera (6042).

As during the previous horizon, many intracategory copresences seem to be significant, for example, the presence of some metal vessel with other types of metal vessel (Figure 7). It is particularly noteworthy that Iberian amphorae are specifically discovered where many Italic amphorae are identified. This pattern occurs on several other matrices in this study and will be examined in the Section "Discussion." Contrary to the Middle Horizon, however, many intercategory co-presences now stand out as particularly significant. The diagonal pattern observed in the previous matrix disappeared. They underlie links (in dark red) among the pieces of jewelry, the hygiene instrumentum, some metallic vessel, and the glass vessel, which are all significantly 

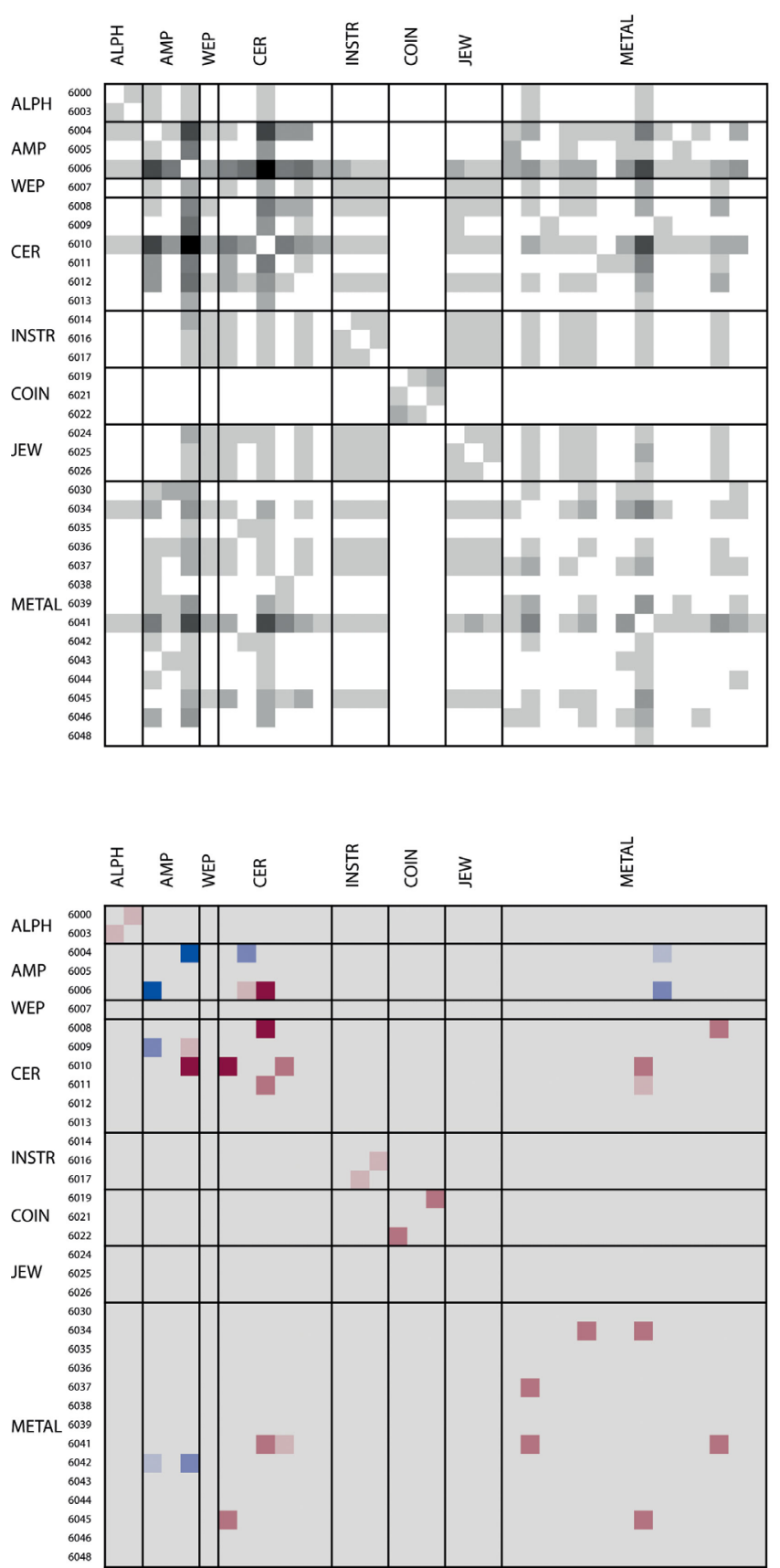

\section{Europe}

Medium Horizon

261 occupations - 13769 objects

\section{Simple co-presence matrix}

\section{Significance score of the co-presences \\ (Significance Matrix)}

$\mathrm{ALPH}=$ Alphabet, $\mathrm{AMP}=$ Amphorae, WEAP $=$ Weapons, $\mathrm{CER}=$ Ceramic wares, $\mathrm{INSTR}=$ Instrumentum, COIN = Coin, $A R T=$ Art object, JEW $=$ Jewellery,$G L A=$ Glass vessel, $M E T A L=$ Metal vessel

FIGURE 6 | Matrices of co-present objects and significance matrix at European scale for the Middle Horizon. ALPH, alphabet; AMP, amphorae; WEAP, weapons; CER, ceramic wares; INSTR, instrumentum; COIN, coin; ART, art object; JEW, jewellery; GLA, glass vessel; METAL, metal vessel.

associated. A similar comment applies to the Italic amphorae (6006) with the ceramic vessel.

An opposite pattern, however, strongly dissociates (in dark blue) the amphorae and the metallic vessel. Both Italic amphorae and late-republican vessel were in full use during the
Recent Horizon. Those two categories are the more numerous imports in this period. Even if many of them are found in the same archeological context (cf. the simple co-presence matrix; Figure 7), the second matrix shows that this couple is significantly less co-present than what we could expect considering 

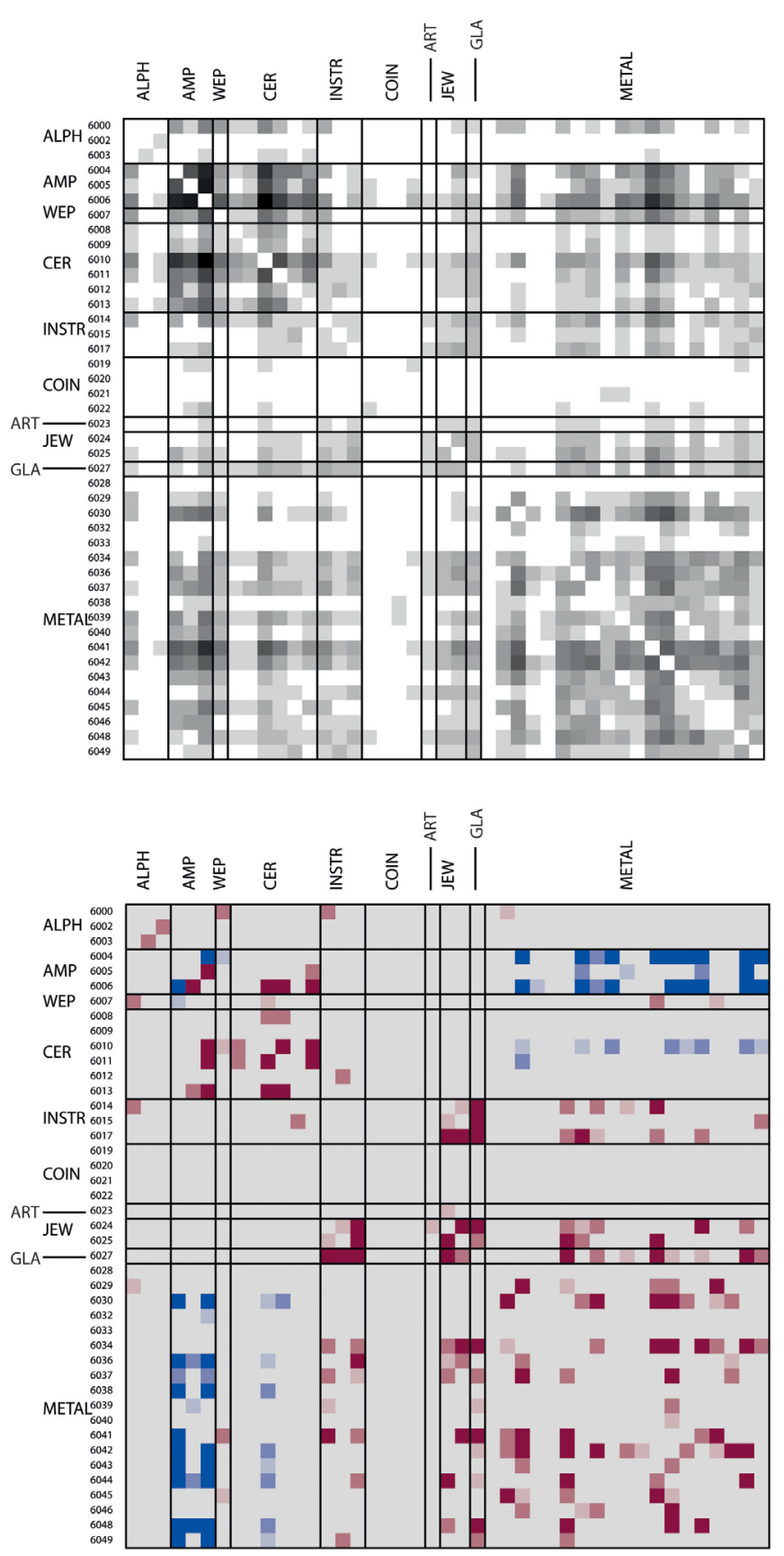

\section{Europe}

Recent Horizon

1009 occupations - 39298 objects

\section{Simple co-presence matrix}

$\mathrm{ALPH}=$ Alphabet, $\mathrm{AMP}=$ Amphorae, $\mathrm{WEAP}=$ Weapons, $\mathrm{CER}=$ Ceramic wares, $\mathrm{INSTR}=$ Instrumentum, COIN = Coin, $A R T=$ Art object, $\mathrm{JEW}=$ Jewellery, $\mathrm{GLA}=$ Glass vessel, $\mathrm{METAL}=$ Metal vessel

FIGURE 7 | Matrices of co-present objects and significance matrix at European scale for the Recent Horizon. ALPH, alphabet; AMP, amphorae; WEAP, weapons; CER, ceramic wares; INSTR, instrumentum; COIN, coin; ART, art object; JEW, jewellery; GLA, glass vessel; METAL, metal vessel.

their number. Many sites should possess either some amphorae or some metallic vessel. This scheme directly refers to the main known trend in the diffusion of Mediterranean imports: they are mostly imported in the western part of Latenian Europe. On the Eastern part, only the metallic vessel predominates.
The Campana ceramics (6010) reflect the exact same opposition against the metallic vessel, underlying again its strong links with the amphorae. Furthermore, the Instrumentum, pieces of jewelry, and the glass vessel, even if strongly correlated with the metal vessel, are, however, normally co-present 
with the amphorae and ceramics. The same remark applies to the ceramic vessels (except the Campana), which are strongly related with amphorae but in normal relationship with the metallic vessel.

This major opposition between the association of Italic amphorae and Campana ceramics in one hand and the metallic vessel in a strong combination with the Instrumentum, the pieces of jewelry, and the glass vessel on the other hand is reminiscent of the well-known East/West distinction. They are clearly identified from the significance matrix. This situation underlines the importance of regional dynamics that remain to analyze. It is then necessary to change the scale of the analysis to be able to differentiate geographical phenomena, highlighting local cultural choices, from the simple problems of frequencies from Western to Eastern Europe.

\section{Regional Scale}

To improve geographical, cultural and historical consistency, five regions were selected and compared (Figure 8). Their extent is explained by the need of a balance between regional specificities and necessary number of sites and artifacts to build the matrices.

First, we chose to zoom on all sites in Great Britain. We simply called the region "England." This is an interesting territory, due to its characteristics as an island. Indeed, it is a closed area and so the best option for a regional study. Also, it is one of the two furthest areas away from the Mediterranean world that we picked, and this is the last region affected by the imports phenomenon at the end of the Iron Age. The area includes several political and cultural territories, both on north and south of the Thames, such as the Dumnonii from Cornwall or the Cantii from Kent.

Then, we studied the sites along the "Channel Coasts," but on the French side, between Brittany and the Seine estuary. We thought that it was interesting to analyze one of the departure zones to the "England" region, in such a way as to be able to compare the situations on both sides of the Channel. Culturally, this region includes the Armoricans and the Celtic territories of the Cotentin.

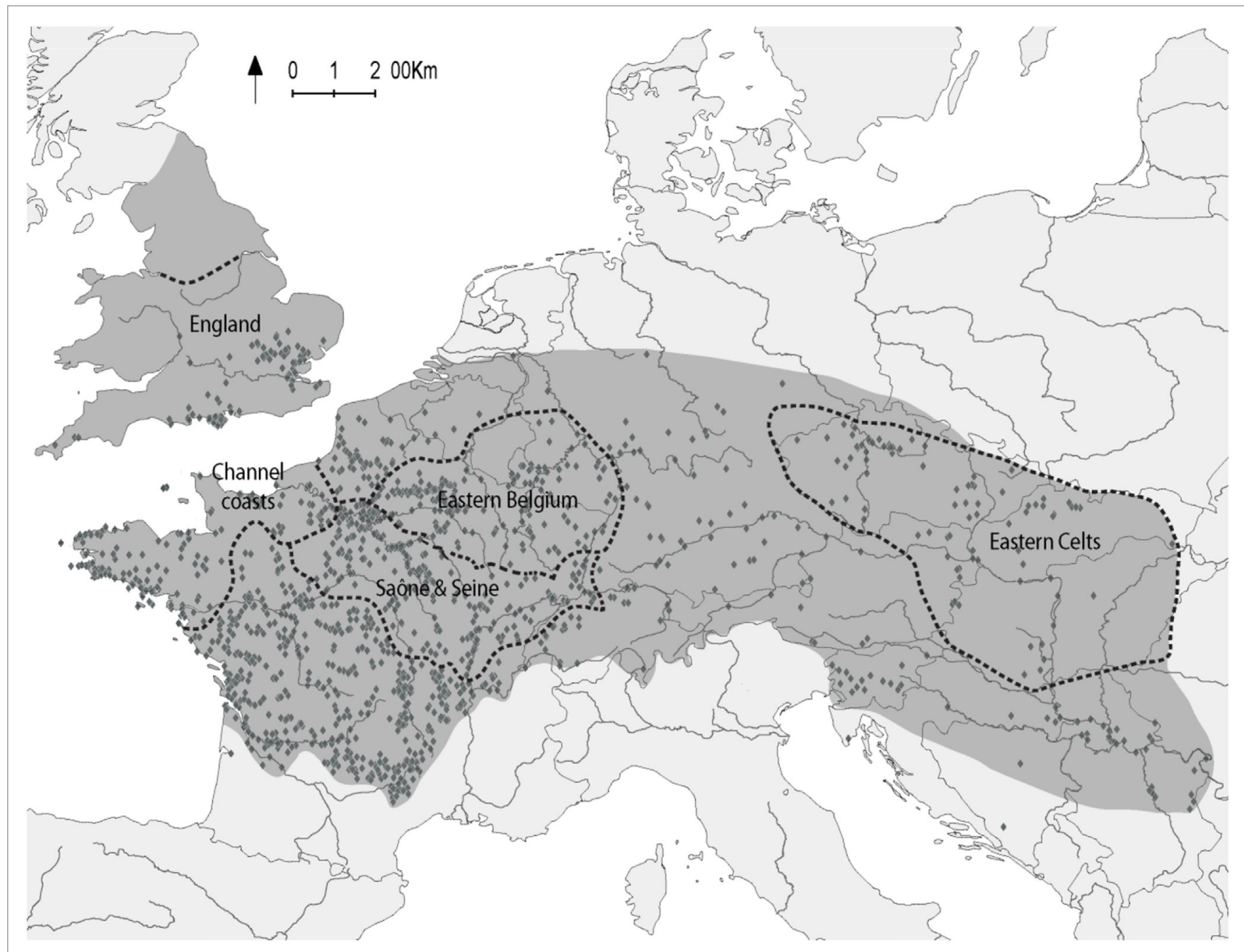

FIGURE 8 | Map of the five regions chosen for the studies 
Third, an area combining "Saône and Seine" valleys has been taken into account. This is the closest zone in Western Europe to the Mediterranean world we chose to study. Also, it is interesting to note that this region stands on one of the most important communication axes, between the north and the south of Europe, along the Rhône, Saône, and Seine valleys. One more thing to take into account is that this area includes very influential populations of central Gaul, such as the Aedui.

The second to the last region is the north-eastern quarter of France, hanging over Belgium and Luxemburg. It is almost the limits of the eastern part of Belgium area, and we thus called it "Eastern Belgium." After the "Saône \& Seine" region, this area can be considered as one of the last steps on the south-north communication axis or rather one possible outlet. We have to specify that this region is very close to the northern border of the Celtic world, but it does not really qualify as a margin. The Celtic populations of this region are associated to the cultural group of the Belgae, and one of their most important tribes, the Treveri (Roymans, 1990).

Finally, as the last point, we chose to pick a region among the eastern Celtic territories, to make comparisons possible. So, we decided to add a fifth region, as "Eastern Celts," defined from Bohemia to the Romanian border. In this region, the most dynamic part is by far Bohemia, which comprises the most active importer sites. This region has the largest surface area, but it is also the less densified area.

As much as possible, we tried to pick regions with the same order of magnitude (Figure 9), while maintaining a historical coherence. Only "Saône \& Seine" possess a significantly high number of objects. This is due to the estimated number of amphorae discovered on the only site of Chalon-sur-Saône $(24,000)$. We can also note that "Eastern Belgium" region has a quite high average number of objects per site (10.7, whereas the other regions are rather around 5-6).

As with the European scale, these five regions were studied through the three chronological horizons, and the number of occupations and objects per horizon is presented in Figure 10.

Only few sites and objects are assigned to the Ancient Horizon, for each region. From there, we decided only to work on the Middle and Recent Horizons. Even with this restriction, we are not able to present the matrices of "England," "Channel Coasts," and "Eastern Celts" for the Middle Horizon. Thus, comparisons between the regions will mostly refer to the Recent Horizon.

\section{"England" Region}

Middle Horizon (250-50 BC): 11 Occupations, 44 Objects (Which Are 44 Amphorae)

As all the imports that were discovered in England during the Middle Horizon belong to a unique type (Dressel 1 A amphorae), it is not possible to work on artifacts associations.

\section{Recent Horizon (150-0 BC): 100 Occupations, 669 Objects, Including 635 Amphorae}

Amphorae and metal vessels are the only two categories imported to the island, except the occurrence of one stylus found in a funerary context, which is an isolated case (Figure 11). The objects of the two categories can be discovered with other objects from their category or from the other one.

None of the types of objects are associated with others less than a random situation (no blue tones on the matrix); that is to say all the observed associations are rather reinforced, unlike the European patterns. Italic and Iberian amphorae types, and also undefined types, are significantly associated with each other, but it seems that the metal vessel is the artifact, which is the most significant with itself. Many associations between different types of metal vessel pieces are more frequent than a predictable situation. Therefore, it should be pointed out that there is a poor number of objects (MNI =33), mostly found in funerary contexts $(\mathrm{MNI}=27)$, which are closed contexts. To take an example, the ablution service (6030 and 6042) is more frequently associated to jugs (6037 and 6040).

Furthermore, the unusual association between tankards and jugs, shown by the matrix, seems to be specific to the England region (the rest of the Celtic world gives priority to cups). Contrary to the European matrix, the amphorae/metal vessel association (dark blue at large scale) is represented by a strong significance in England (red at regional scale), notably the bucket-Iberian amphora pair, which is mostly found in funerary contexts. These opposite situations show the importance of the regional options.

The last point to note is that there is no ceramic vessel in England at all, contrary to the situation observed in the "Channel Coasts" region (see below). Apparently, this kind of imports does not cross the Channel.

\section{"Channel Coasts" Region}

Middle Horizon: 33 Occupations, 438 Objects, Including 437 Amphorae

During the Middle Horizon, the "Channel Coasts" region stands out by possessing a sufficient amount of objects (438 artifacts), but a weaker diversity than the other regions (Figure 12). Indeed, there are only two categories but the co-presences concern almost always the amphorae types. None of the sites of this region possessed ceramic or metal vessels, linked to wine consumption. In fact, 437 amphorae have been counted against only 1 ceramic vessel piece. This important number of objects, already in the Middle Horizon, is notably due to the site of Paule (Côte-d'Armor) and its capacity to bring and concentrate Roman imports (372 amphorae).

\section{Recent Horizon: 90 Occupations, 240 Objects, Including 222 Amphorae}

At the Recent Horizon (Figure 12), the situation changes gradually. The amphorae category still dominates the other ones, but now we can notice the presence of the ceramic and metal vessel pieces and weapons. These categories take part in intracategory and intercategory associations.

Emphasis is notably given to the pair composed by a strong proportion of Italic amphorae and a weak presence of Iberian amphorae, but, unlike England region, mainly on settlements [in south Finistère and in the East of the region (Eure department), around the Seine valley]. 


\begin{tabular}{|c|c|c|c|c|}
\hline & Occup nb & MNI & $\begin{array}{c}\text { Average nb of } \\
\text { objects per site }\end{array}$ & $\begin{array}{c}\text { Median of } \\
\text { MNI }\end{array}$ \\
\hline England & 129 & 742 & 5,8 & 2 \\
\hline Channel coasts & 190 & 822 & 4,3 & 1 \\
\hline Saône \& Seine & 330 & 33576 & 101,7 & 2 \\
\hline $\begin{array}{c}\text { Eastern } \\
\text { Belgium }\end{array}$ & 205 & 1871 & 9,1 & 1 \\
\hline Eastern Celts & 128 & 598 & 4,7 & 1 \\
\hline
\end{tabular}

FIGURE 9 | The table shows the number of occupations, the number of objects (MNI), the average number of objects per site, and the median of MNI for each selected area.

\begin{tabular}{|c|c|c|c|c|c|c|}
\hline & \multicolumn{2}{|c|}{$\begin{array}{c}\text { ANCIENT } \\
\text { HORIZON }\end{array}$} & \multicolumn{2}{c|}{$\begin{array}{c}\text { MIDDLE } \\
\text { HORIZON }\end{array}$} & \multicolumn{2}{c|}{$\begin{array}{c}\text { RECENT } \\
\text { HORIZON }\end{array}$} \\
\cline { 2 - 7 } & $\begin{array}{c}\text { Occup } \\
\text { nb }\end{array}$ & MNI & $\begin{array}{c}\text { Occup } \\
\text { nb }\end{array}$ & MNI & $\begin{array}{c}\text { Occup } \\
\text { nb }\end{array}$ & MNI \\
\hline England & $1 ?$ & $1 ?$ & 11 & 44 & 100 & 669 \\
\hline $\begin{array}{c}\text { Channel } \\
\text { coasts }\end{array}$ & 3 & 4 & 33 & 438 & 90 & 240 \\
\hline $\begin{array}{c}\text { Saône \& } \\
\text { Seine }\end{array}$ & 10 & 323 & 40 & 2236 & 194 & 30092 \\
\hline $\begin{array}{c}\text { Eastern } \\
\text { Belgium }\end{array}$ & 4 & 4 & 41 & 214 & 121 & 1561 \\
\hline $\begin{array}{c}\text { Eastern } \\
\text { Celts }\end{array}$ & 7 & 16 & 9 & 10 & 44 & 276 \\
\hline
\end{tabular}

FIGURE 10 | The table presents the number of occupations and objects per horizon and per region.

Although the metal vessel is booming during the Recent Horizon and there are already 33 pieces of metalvessels in England, there are just four objects on this side of the Channel. Indeed, among those, three strainers have been found on three different sites, also containing amphorae. The matrix seems to be showing a specific significance between strainers and weapons, but we think that this example shows the limit of this method. Because of the poor number of weapons ( $1 \%$ of the entire corpus), scattered only in the west half of Celtic Europe, significant co-presences with the other objects are highlighted in this region, in comparison with the European schemas. To solve the problem, we may proceed to a significance study region by region. We ruled this option out because it considerably reduces the number of artifacts and sites, increasing de facto the number of potential statistical errors. At the end, no significant association could remain.

\section{"Saône \& Seine" Region}

Middle Horizon: 40 Occupations, 2,236 Objects, Including 2,044 Amphorae

The matrices of the "Saône \& Seine" region are relatively different from the previous ones (Figure 13). Indeed, it is already possible to observe a structured pattern, which consists of copresences between only 3 of 10 categories: amphorae, ceramics, and metal vessels. That means that the import choices are very selective at an early stage. The clear association between Italic amphorae (6006), Campana ceramic vessels (6010), and one particular type of metal vessel (strainers-6041) is particularly significant, and all the three categories interact with themselves.

A specific association, between ceramic and metal vessels, composed of strainers (6041) and Campana and common ceramics $(6010,6011)$ is one of the two most significances of the matrix. It is interesting to note that this association is also significant at the European scale, as well as the association of Italic amphorae (6006) and the different types of ceramics (6009-6011).

However, the metal vessels associations are built on a different pattern from the European distribution. The specific association of Kelheim jugs, strainers, and ladles are significant for this region and, together they form the beginning of a wine service, not observed at the European scale during this period.

\section{Recent Horizon: 194 Occupations, 30,092 Objects, Including 29,576 Amphorae: 24,000 from Chalon-sur-Saone}

The matrix is now denser (Figure 13). Some tendencies observed in the Middle Horizon are accentuated. New categories and new types also appear, such as the presence of weapons (6007) or instrumentum pieces (but only for writing-6014).

The clear association between Italic types of amphorae and Campana ceramics, all linked to wine consumption, observed for the Middle horizon, is still valid. The Italic amphorae and the ceramic for wine consumption appear as the basic association, which is present in a large number of sites. The link between the Campana ceramics and the common ceramic vessels, a European-scale feature, still continue at this chronological step, whereas the association between Italic amphorae, Campana ceramics, and strainers disappears. This regional characteristic is surprising, knowing that these items are the most widespread.

The 229 weapons are mostly present on some important fortified sites (Bibracte, Alésia, or Basel), if this category is more significant than the predictable model, it may well be caused by targeted deliveries, specifically in the huge import centers, where the items are co-present with the other imported products.

The European association between the use of Greek alphabet and the writing instrumentum is also emphasized in the "Saone \& Seine" region (composed of 54 Greek alphabets uses and 18 stylets and seal boxes). This significant pair seems to be logical but deserved to be underlined for the preconquest period.

In this region, the three different metal vessel services (ablution, preparation, and service) are represented by the different types of metal vessel pieces (19 types of 21). However, even if the metal vessel is the third most imported category in this region (Figure 13), the corresponding square of intracategory co-presences shows the absence of specific significance (red or blue). This is very far from the European dense red pattern. Thus, the different pieces are neither significantly associated nor significantly dissociated. They just fit to the random situation. It is even more surprising because of the period (full use of late republican Roman metal vessels in the Celtic world) and the way these objects must be used, in several pieces services. 


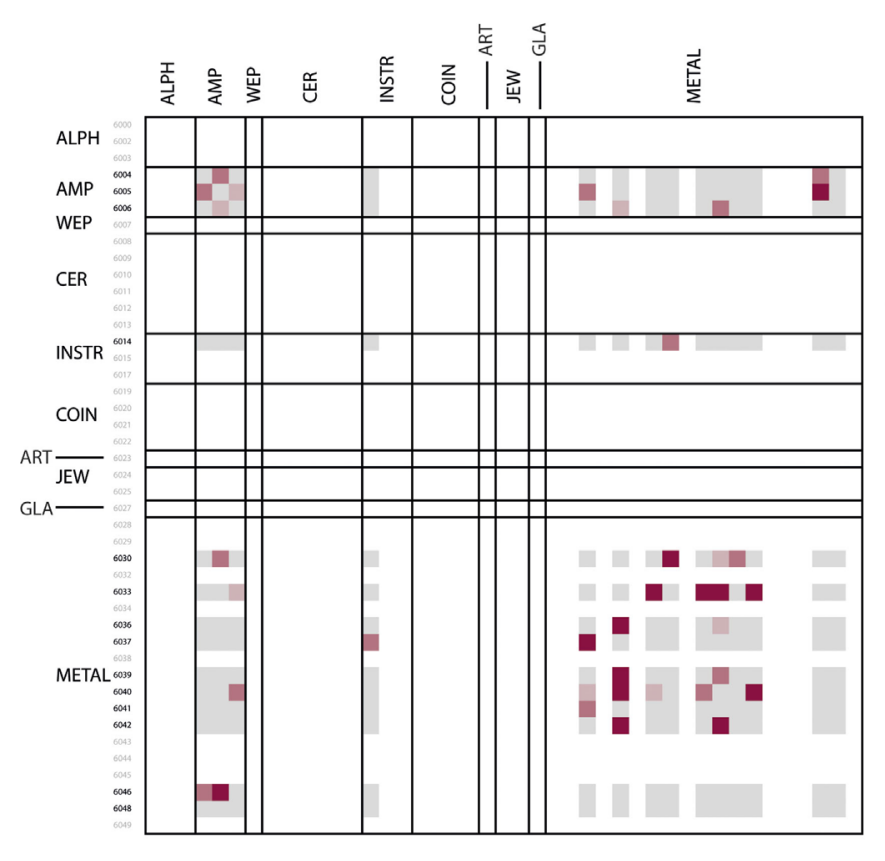

\section{England}

\section{Recent Horizon \\ 100 occupations - 669 objects}

\begin{tabular}{|c|c|c|}
\hline $\begin{array}{c}\text { MNI by } \\
\text { horizon }\end{array}$ & Middle & Recent \\
\hline Amphorae & 44 & 635 \\
\hline Metal vessel & 0 & 33 \\
\hline Instrumentum & 0 & 1 \\
\hline Weapon & $\mathbf{0}$ & $\mathbf{0}$ \\
\hline Ceramics & $\mathbf{0}$ & $\mathbf{0}$ \\
\hline Greek alphabet & $\mathbf{0}$ & $\mathbf{0}$ \\
\hline Coin & $\mathbf{0}$ & $\mathbf{0}$ \\
\hline Art & $\mathbf{0}$ & $\mathbf{0}$ \\
\hline Jewelleries & $\mathbf{0}$ & $\mathbf{0}$ \\
\hline Glass & $\mathbf{0}$ & $\mathbf{0}$ \\
\hline
\end{tabular}

$\mathrm{ALPH}=$ Alphabet, $\mathrm{AMP}=$ Amphorae, $\mathrm{WEAP}=$ Weapons, $\mathrm{CER}=$ Ceramic wares, INSTR $=$ Instrumentum, COIN $=$ Coin, ART $=$ Art object, $\mathrm{JEW}=$ Jewellery, $\mathrm{GLA}=$ Glass vessel, $\mathrm{METAL}=$ Metal vessel

FIGURE 11 | Matrix for the "England" region at the Recent Horizon and table of the MNI objects in "England" region per category for Middle and Recent Horizons. ALPH, alphabet; AMP, amphorae; WEAP, weapons; CER, ceramic wares; INSTR, instrumentum; COIN, coin; ART, art object; JEW, jewellery; GLA, glass vessel; METAL, metal vessel.

\section{"Eastern Belgium" Region}

Middle Horizon: 41 Occupations, 214 Objects, Including 197 Amphorae

With 41 occupations, the "Eastern Belgium" region has the same number of occupations as the "Saône \& Seine" region, but the number of objects is much less important (214 against 2,236; Figure 14). Indeed, the Middle Horizon matrix is less dense, and the co-presences are very scattered.

The situation is quite different from that in the neighboring region, at the same period. Regarding the types, we can note that it is the same amphorae and ceramics types as in "Saône \& Seine" region (Italic amphorae-6006 and the less frequent ceramics-6009), but their behavior is different. In this region, there is no association inside a given category, which is particularly significant. We can argue that it could mean an important homogeneity inside the Amphorae and Ceramic categories. Indeed, Italic amphorae represent more than $90 \%$ of the amphorae corpus of this region $(\mathrm{MNI}=180 / 197)$.

Regarding the metal vessel, two types are favored in this region, namely the basins, very significant in association with Iberian amphorae, and the patera (two pieces from the ablution service) associated with ceramics (6009). Here, the strainers are rare, whereas they are very numerous in the southern region. In addition, they are never co-present with amphorae and ceramics, and their presence is as significant as a random distribution.

Another difference with the "Saône \& Seine" region is the presence of a piece of jewelry (one undefined discovered on a fortified site) that brings just a touch of originality to the Middle Horizon matrices.

\section{Recent Horizon: 121 Occupations, 1,561 Objects, Including 1,345 Amphorae}

We are faced here again with a matrix schema very different from the European situation (Figure 14). Comparing the matrices of the Middle and Recent Horizons, we may say that the situation does not evolved a lot. Indeed, even in the most recent period, there are not so much significant co-presences; all are more present than predictable. Also, there are still not so much intracategory significant co-presences, and metal vessels are the only objects concerned. However, none of the co-presences are the same as in the previous horizon. Different types of amphorae, ceramics, or metal vessel are significantly associated.

Regarding amphorae, the recurrent Italic type (6006; MNI $=800$ ) of the first century BC stands alongside the undefined amphorae (6004), mostly in association with strainers 


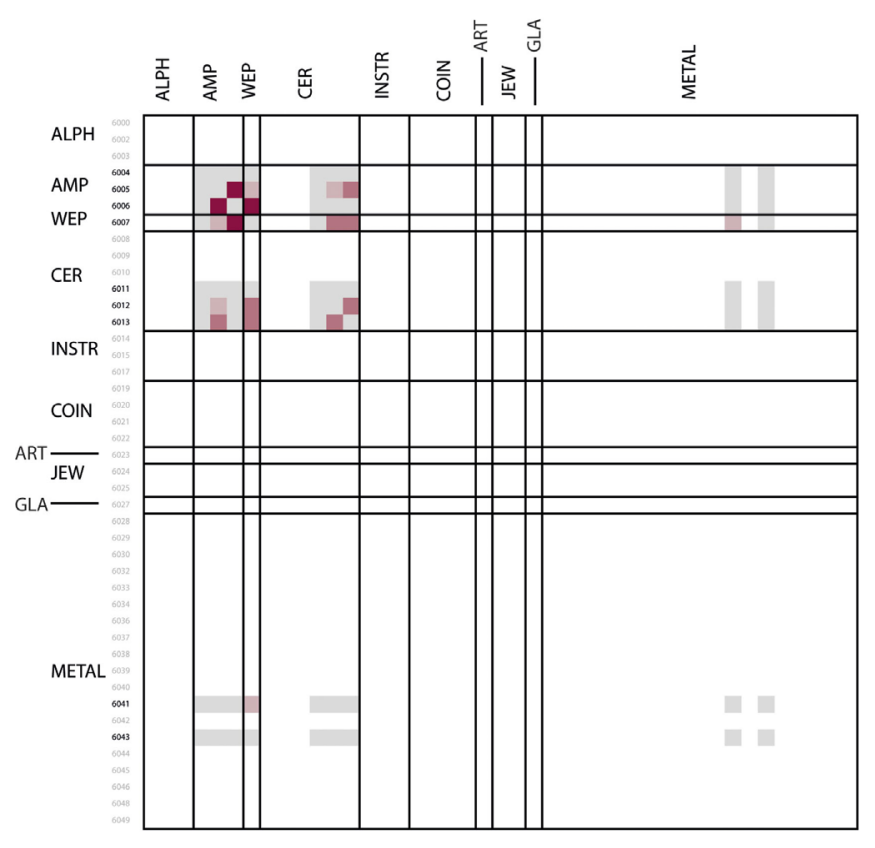

\section{Channel Coasts}

Recent Horizon

\begin{tabular}{|c|c|c|}
\hline $\begin{array}{c}\text { MNI by } \\
\text { horizon }\end{array}$ & Middle & Recent \\
\hline Amphorae & 437 & 222 \\
\hline Ceramics & 1 & 5 \\
\hline Weapon & 0 & 9 \\
\hline Metal vessel & 0 & 4 \\
\hline Greek alphabet & 0 & 0 \\
\hline Instrumentum & 0 & 0 \\
\hline Coin & 0 & 0 \\
\hline Art & 0 & 0 \\
\hline Jewelleries & 0 & 0 \\
\hline Glass & 0 & 0 \\
\hline
\end{tabular}

$\mathrm{ALPH}=$ Alphabet, $\mathrm{AMP}=$ Amphorae, $\mathrm{WEAP}=$ Weapons, $\mathrm{CER}=$ Ceramic wares, INSTR $=$ Instrumentum, COIN $=$ Coin, ART $=$ Art object, $\mathrm{JEW}=$ Jewellery, $\mathrm{GLA}=$ Glass vessel, $\mathrm{METAL}=$ Metal vessel

FIGURE 12 Matrix for the "Channel Coasts" region at Recent Horizon and table of the MNI objects in "Channel Coasts" region per category for Middle and Recent Horizons. ALPH, alphabet; AMP, amphorae; WEAP, weapons; CER, ceramic wares; INSTR, instrumentum; COIN, coin; ART, art object; JEW, jewellery; GLA, glass vessel; METAL, metal vessel.

(6041; MNI = 38), which were absent before. For the ceramics, the focus is on the Campana types $(6010 ; \mathrm{MNI}=54)$, also in regular association with strainers.

Concerning the metal vessel, unless strainers as seen just above, the associations for the other types are not so obvious, except between jug (6040) and patera (6042).

This region is very interesting to study for its chronological evolution from the Middle to the Recent Horizons. No clear organization arose before; now it appears that this region made imports choices showing a determination to drink wine in accordance with the Mediterranean practices, as reflected by the significant co-presences between Italic amphorae, Campana ceramics, and pieces of the service for wine preparation (strainers above all).

\section{"Eastern Celts" Region}

Recent Horizon: 44 Occupations, 276 Objects, Including 21 Amphorae and 183 Metal Vessel Pieces

This is the only picture we have of the situation in the East of Europe (Figure 15). Moreover, the few numbers of occupations and objects did not allow us to draw a matrix for the Middle Horizon. We can just study the matrix of the Recent Horizon. However, it readily appears that it is much different from all the other regions but all at once, it is certainly the matrix closest of to European pattern. All the represented types are associated to intracategories and intercategories relations.

First, for the first time, the metal vessel is predominantly significant intracategories and intercategories, as well as the instrumentum, glass vessel, and pieces of jewelry categories. These features constitute a whole different pattern in comparison to the four other regions.

The presence of the ceramic vessel is mostly non-significant. The exception is the "negative relation" between the Campana type (6010) with all the types of amphorae, which shows a total dissociation of these two categories. That also is a new categorical schema.

Finally, the amphorae must be mentioned for their very specific features in central Europe. Their co-presences with themselves and ceramic and metal vessels are particularly less significant in this area than everywhere else, notably because they infrequently reach the East of the Celtic world, depicting an unprecedented situation.

This significance matrix is probably the most interesting of all to show the weight of the regional differences in European studies, the necessity to work at varied scales and particularly when zooming on specific regions, as the Eastern Celts area. Indeed, glass vessels, instrumentum, and pieces of jewelry, associated with numerous sets of metal vessels and the absence 

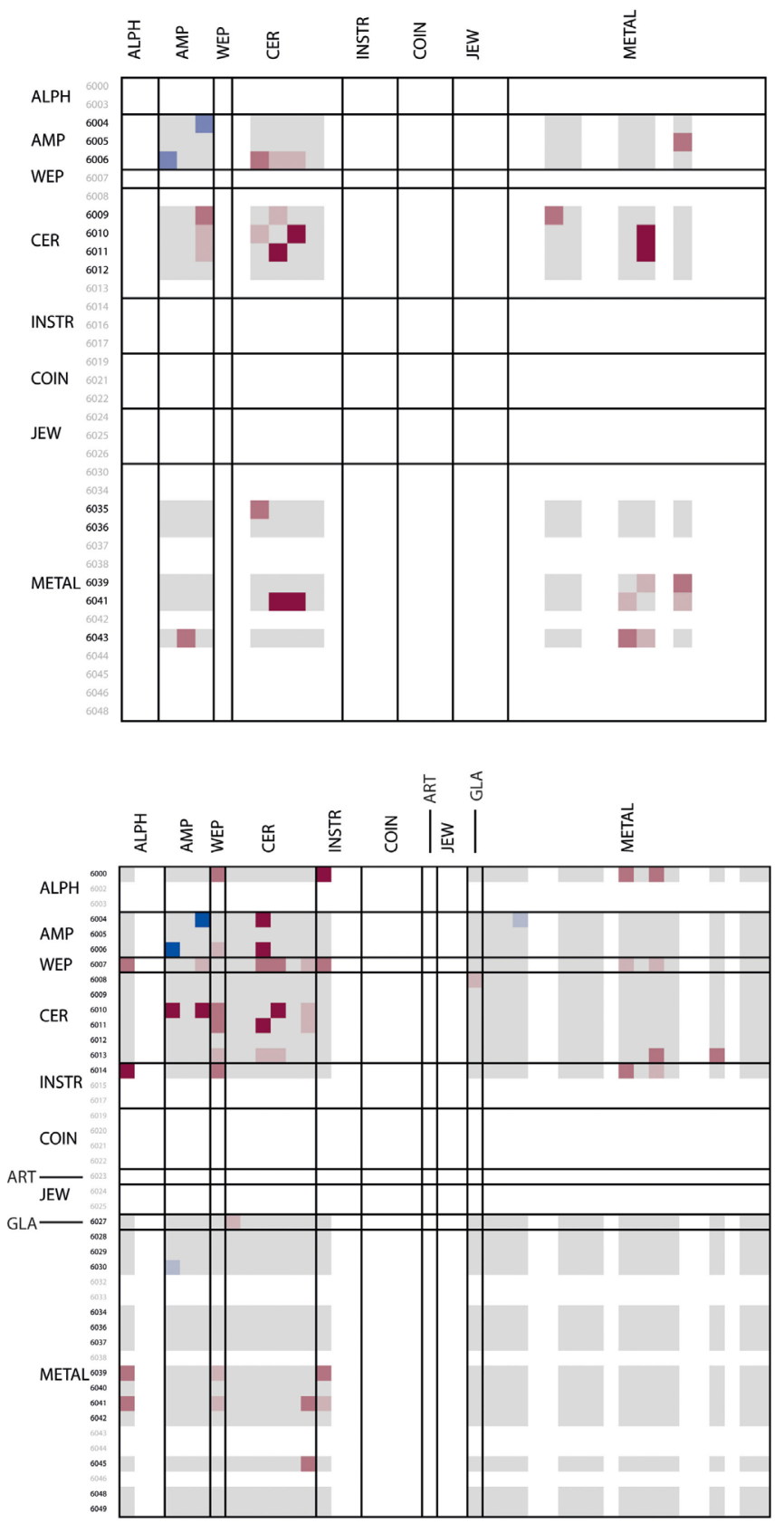

\section{Saône \& Seine}

\section{Medium Horizon}

40 occupations - 2236 objects

\begin{tabular}{|c|c|c|}
\hline $\begin{array}{c}\text { MNI by } \\
\text { horizon }\end{array}$ & Middle & Recent \\
\hline Amphorae & 2044 & 29576 \\
\hline Ceramics & 180 & 99 \\
\hline Metal vessel & 12 & 102 \\
\hline Weapon & 0 & 229 \\
\hline Greek alphabet & 0 & 54 \\
\hline Instrumentum & 0 & 18 \\
\hline Glass & 0 & 15 \\
\hline Coin & 0 & 0 \\
\hline Art & 0 & 0 \\
\hline Jewelleries & 0 & 0 \\
\hline
\end{tabular}

Recent Horizon

194 occupations - 30092 objects

$\mathrm{ALPH}=$ Alphabet, $\mathrm{AMP}=$ Amphorae, $\mathrm{WEAP}=$ Weapons, $\mathrm{CER}=$ Ceramic wares, $\mathrm{INSTR}=$ Instrumentum, COIN $=$ Coin, $A R T=$ Art object, $\mathrm{JEW}=$ Jewellery, GLA $=$ Glass vessel, METAL $=$ Metal vessel

FIGURE 13 | Matrices for the "Saône \& Seine" region at Middle and Recent Horizons and table of the MNI objects in "Saône \& Seine" region per category for Middle and Recent Horizons. ALPH, alphabet; AMP, amphorae; WEAP, weapons; CER, ceramic wares; INSTR, instrumentum; COIN, coin; ART, art object; JEW, jewellery; GLA, glass vessel; METAL, metal vessel.

of amphorae, draw a pattern reflecting the specificity of local import choices.

To conclude, we can say that the regional approach allows us to better understand the geographical differences in the way imported artifacts are tied to one another. Indeed, at the European scale, the very heavy weight of amphorae in the west of Europe prevents us from viewing a part of the other phenomena. Helped with the regional scale, amphorae proportions were not a problem 


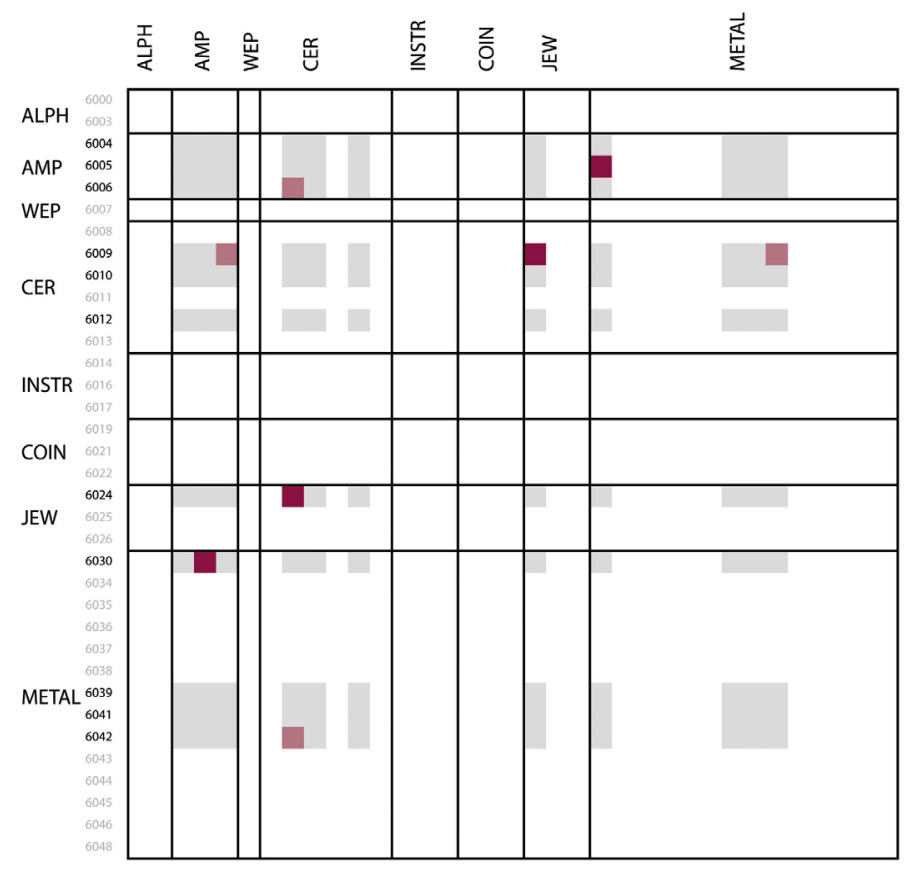

\section{Eastern Belgium}

\section{Medium Horizon}

41 occupations - 214 objects

\begin{tabular}{|c|c|c|}
\hline $\begin{array}{c}\text { MNI by } \\
\text { Horizon }\end{array}$ & Middle & Recent \\
\hline Amphorae & 197 & 1345 \\
\hline Metal vessel & 12 & 96 \\
\hline Ceramics & 4 & 61 \\
\hline Jewelleries & 1 & 2 \\
\hline Weapon & 0 & 47 \\
\hline $\begin{array}{c}\text { Greek } \\
\text { alphabet }\end{array}$ & 0 & 5 \\
\hline Coin & 0 & 3 \\
\hline Instrumentum & 0 & 2 \\
\hline Art & 0 & 0 \\
\hline Glass & 0 & 0 \\
\hline
\end{tabular}

Recent Horizon

121 occupations - 1561 objects

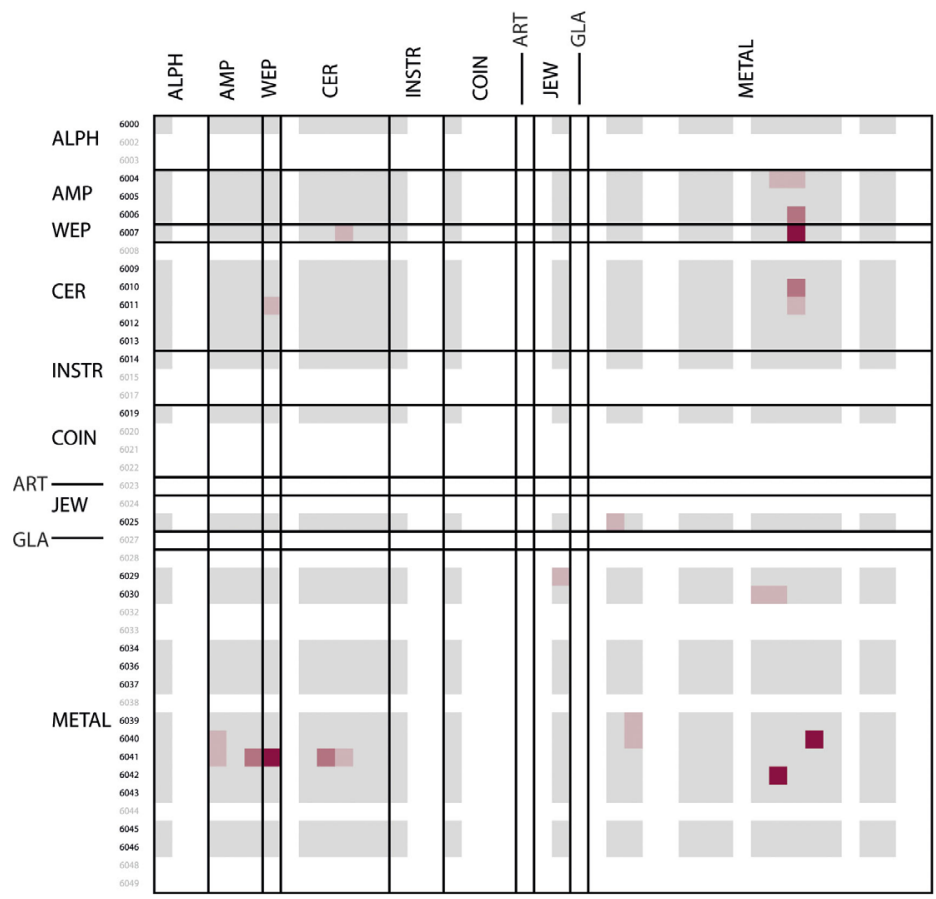

$\mathrm{ALPH}=$ Alphabet, $\mathrm{AMP}=$ Amphorae, $\mathrm{WEAP}=$ Weapons, $\mathrm{CER}=$ Ceramic wares, INSTR $=$ Instrumentum, $\mathrm{COIN}=$ Coin, $\mathrm{ART}=$ Art object, $\mathrm{JEW}=$ Jewellery, $\mathrm{GLA}=$ Glass vessel, $\mathrm{METAL}=$ Metal vessel

FIGURE 14 | Matrices for the "Eastern Belgium" region at Middle and Recent Horizons and table of the MNI objects in "Eastern Belgium" region per category for Middle and Recent Horizons. ALPH, alphabet; AMP, amphorae; WEAP, weapons; CER, ceramic wares; INSTR, instrumentum; COIN, coin; ART, art object; JEW, jewellery; GLA, glass vessel; METAL, metal vessel. 


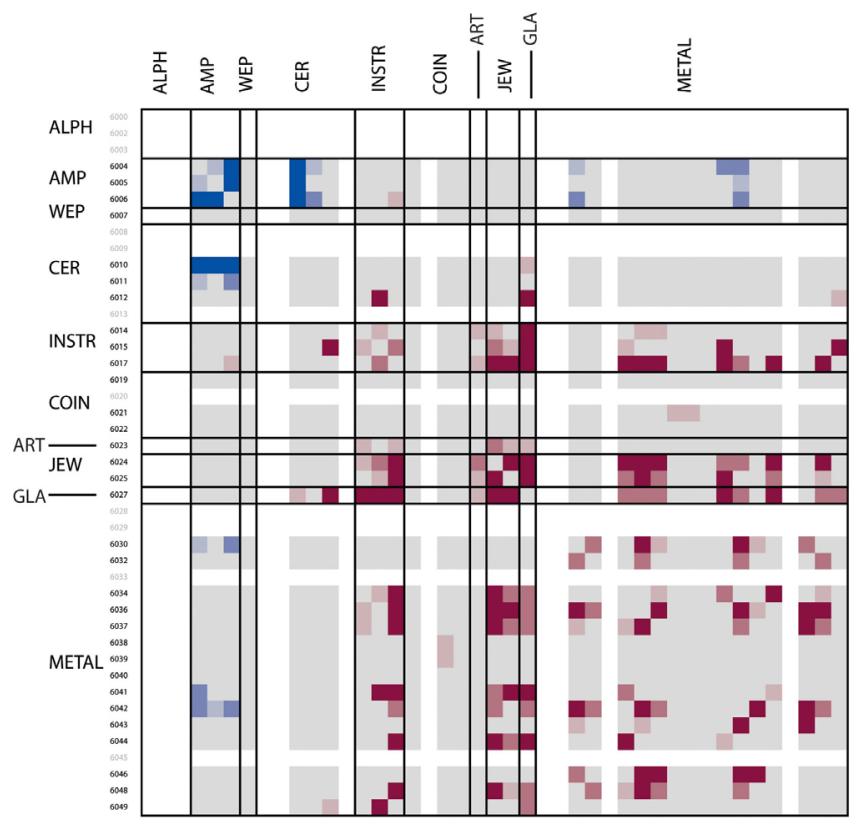

$\mathrm{ALPH}=$ Alphabet, $\mathrm{AMP}=$ Amphorae, $\mathrm{WEAP}=$ Weapons, $\mathrm{CER}=$ Ceramic wares, $\mathrm{INSTR}=$ Instrumentum, $\mathrm{COIN}=$ Coin, $\mathrm{ART}=$ Art object, $\mathrm{JEW}=$ Jewellery, $\mathrm{GLA}=$ Glass vessel, METAL $=$ Metal vessel

\section{Eastern Celts}

\author{
Recent Horizon \\ 44 occupations - 276 objects
}

\begin{tabular}{|c|c|c|}
\hline $\begin{array}{c}\text { MNI by } \\
\text { horizon }\end{array}$ & Middle & Recent \\
\hline Metal vessel & 7 & 183 \\
\hline Jewelleries & 3 & 9 \\
\hline Instrumentum & 0 & 41 \\
\hline Amphorae & 0 & 21 \\
\hline Glass & 0 & 8 \\
\hline Ceramics & 0 & 6 \\
\hline Coin & 0 & 5 \\
\hline Art & 0 & 2 \\
\hline Weapon & 0 & 1 \\
\hline Greek alphabet & 0 & 0 \\
\hline
\end{tabular}

FIGURE 15 | Matrix for the "Eastern Celts" region at the Recent Horizon and table of the MNI objects in "Eastern Celts" region per category for Middle and Recent Horizons. ALPH, alphabet; AMP, amphorae; WEAP, weapons; CER, ceramic wares; INSTR, instrumentum; COIN, coin; ART, art object; JEW, jewellery; GLA, glass vessel; METAL, metal vessel.

for matrices construction anymore. Controlling geographical and time factors, we can, as of now, focus on economic and social structures.

\section{DISCUSSIONS}

\section{About the Results}

A general observation is that each regional matrix shows a very specific co-presence schema. If all those regions imported Mediterranean artifacts, it seems that they all made their own blend from the Mediterranean offer. It can be used as an element suggesting some active selections rather than passive integration of those artifacts by Celtic societies. We do not just work on Greek and Roman selective exports rather than specific imports chosen by the different Celtic people. This study effectively deals with the supply (-ies) and the demand (-s).

Another general observation on the seven regional matrices is that the regional restrictions induce more often the discovery of significant associations rather than significant dissociations. This supports our primary hypothesis: geographical restrictions uncover significant co-presences that were not significant at the European level. Indeed if significant dissociations were found repeatedly at the regional levels, it would indicate that sites on which the corresponding artifacts were co-present are spread all over Europe.

\section{"Saône \& Seine" and "Eastern Belgium" Regions}

Of our five selected zones, the "Saône \& Seine" region is the closest to the Mediterranean Sea. It is considered as a major circulation axis since the Bronze Age and should have played a key role in the diffusion of Mediterranean imports in Gaul, in particular in the Western regions that are studied in this article.

The favored position of this region, along this axis used to convey Roman imports, accentuates the idea of a cultural proximity between those Celtic civitates and the Roman Republic. The link between the Aedui tribe and the Italic leading class is also well known (Caesar, BG, I, 33). For these precise reasons, we thought it could be the region where the Mediterranean drinking wine practices were the most replicated. During the Middle horizon, the significant relations are, in one hand, between strainers and Campana ceramics, and on the other hand, between Campana ceramics and Italic amphorae. There is no particular association between strainers and Italic amphorae, but we could already see the mentioned relations as the beginning of a drinking consumption set. That said, the chronological evolution may be surprising notably because of the absence of the metal vessels in significant relations with amphorae, even if there are both present on the same sites (co-presences relations). At the Recent Horizon, the adoption of the Roman wine consumption (29,576 amphorae have been recorded in this region), as well as the diversification of imports 
in other spheres of the everyday life (reflecting cultural practices from Roman Republic like types of ceramic used for Italic cooking methods like frying), nevertheless give a conflicting picture of Celtic societies trying to imitate the Mediterranean world way of life while adopting specific practices with this exogenous material (amphorae and pieces of drinking vessels not specifically associated). Could we make the hypothesis that, in this region, wine became such a "daily" product, so far as it was not specifically associated with formal vessels anymore? As explained in the Section "Methodology," this conclusion might be too strong, as having non-significant co-presences does not rule out a deliberate association between the artifacts. This is typically a question that could be explored in more details given additional data.

This region is also the best example to talk about the weapons "imports." With the coins, it is one of the most difficult categories to interpret, because of its hybrid status. The presence of Roman weapons is not necessarily due to economic imports, in the true sense of the term. It can refer to other ways of procurement. As far as possible, we tried to avoid recording weapons associated to the Roman military presence and looked for items, which most probably crossed the cultural frontiers. Thus, there are many records of gladii (sword) and pugiones (dagger) discovered on the main fortified sites of the Celtic world (Corent, Bibracte, Essey-lès-Nancy, Basel, Titelberg, Port-en-Bessin, etc.) and in funerary contexts (Esvres-sur-Indre, Guibiasco, Berry-Bouy, Pitres, etc.). The recurrence of the weapon presences in the main import centers of the Celtic world may be one reason for their numerous significant relations with the other categories in this particular region (Greek alphabets, amphorae, ceramic vessels, instrumentum, and metal vessels).

The "Eastern Belgium" consists of a neighboring region of our "Saône \& Seine" area. The merchandises coming from the Mediterranean Sea should have a priori been transported across the "Saône \& Seine" region to join the "Eastern Belgium" zone.

The modifications between the Middle and the Recent horizon are certainly the most radical among all the regions: none of the significant associations of the Middle horizon are shared during the Recent horizon. If the patterns of the Middle horizon seem to be scattered (with regard to diverse categories), the Recent Horizon schemas are organized around a group of three specific item types, as to know: Italic amphorae (6006), Campana ceramics (6010), and strainers (6041). Can we consider these three types as a complete set for the wine consumption in the Celtic world? It is tempting!

The two regions, which can be considered on the same economical journey for Mediterranean products traveling to the north, seem to share a specific association between amphorae (Italic), metal (strainers), and ceramic vessels (Campana), but not at the same period. Indeed, we can observe a chronological gap: this set is associated, more or less, in the Middle horizon in "Saône and Seine" region and in the Recent Horizon in "Eastern Belgium," as it could match to a diffusion of this wine consumption way to the north of the Celtic world. We can precise that these specific items are the most numerous of their category and also the most widespread. This specific trio is present on 26 occupations all over the studied area. Among these 26, 4 occupations are discovered in "Eastern Belgium" and 8 of them in "Saône and Seine" region. Accumulated, it is almost half of the global number. Thus, it is in this corridor that the wine consumption set trio is the most present. The main delivery way would also be the main diffusion vector of the Roman culture.

\section{"England" and "Channel Coasts" Regions}

The "England" region is situated at the border of the diffusion area of Mediterranean imports. The absence of ceramic wares is the most distinctive feature of this area. Unlike the other regions, the English area imported a few number but a quite large variety of metal vessels. It appears as an occasional supply that is mostly discovered on sites also importing some amphorae. Regional studies already highlighted that those imports are particularly linked with the funerary contexts of eastern England, north of the Thames (Carver, 2001). This observation should also be highlighted by dividing co-presences matrices between settlements and funerary contexts. That remains to be done in the future.

This east/west difference could also come from the history of the imports deliveries in England, which used two main entries. This hypothesis needs to be studied from the two sides of the Channel. The first statements we suggested here intend, in a first step, to provide a new material to perceive the links in the way populations of both sides of the Channel consumed Mediterranean imports between England and the Channel Coasts areas on the one hand and between England and the northern Gaul on the other hand.

The "Channel Coasts" matrices can be summarized to a major association involving amphorae and ceramic vessels, at both the Middle and Recent Horizons. However, we cannot perceive the same recurrent combination of Italic amphorae and Campana vessels that characterizes the other areas. The slow regional evolution causes the structured sets used for wine consumption to be invisible, even in the most Recent Horizon. Moreover, the fact that the number of amphorae diminishes during that time whereas the imports types tend to diversify, a situation observed nowhere else, is clearly one of the leads we have to follow to better understand the decisions made by these populations.

Also, the absence of metal vessels must be underlined. Indeed, the effectives of these items are higher for all the neighboring regions, even in "England" region (33 metal vessel pieces in the Recent Horizon). We could argue that in this region there is no deficiency of the supply network rather than a rational choice, very selective, favoring the amphorae above everything else.

These two regions, studied together, also interested us. We wanted to be able to compare the imported items on both sides of the Channel. The presence of ceramic vessel was very anecdotal during the Recent Horizon (five items), and moreover they did not achieve English shores. The general distribution of this category is gradually reduced from the south of Gaul to the north. We can wonder if the absence in English contexts is due to a lack of delivery or if it is a choice of the Britton populations, as in "Channel coasts" region.

Then, an interesting connection, highlighted by both the European and the English matrices, but also in "Channel coasts" region, is the link between Italic and Iberian amphorae, at the Recent horizon. The effectives of these two types are not 
comparable (more than 30,000 Italic amphorae and only less than 300 Iberian amphorae recorded in the database for the entire Celtic world). Trying to understand why regions, where Italic amphorae were numerous, also imported Iberian amphorae, from the first century BC, we can suppose that it maybe due to:

- to taste other wine varieties,

- to stand out from the other sites and to show more power,

- because of the specificities of deliveries methods and actors,

- or in a more pragmatic way, due to the lower cost of the Catalonia wine production (Cunliffe, 1993:160),

- and preferentially a mix of all of these reasons.

Now we established the link between those two types of Amphorae, we have to examine the contexts of these finds to evidence a functional relation in their use (domestic consumptions, funerary practices, etc.).

\section{“Eastern Celts" Region}

As already highlighted (Pierrevelcin, 2012), the "Eastern Celts" region comes out as distinctly different from Western Europe (specific chronological evolution, local material culture, particular funerary practices, etc.). This is also true in the case of imports field. Indeed, this regional matrix is really different than the others and highlights numerous significant associations never seen elsewhere between metal and glass vessel, instrumentum, and jewelry categories.

The few discovered amphorae in this area partly belong not only to a specific type produced on the east coast of the Italian peninsula, the Lamboglia 2, but also to the types discovered on the western part of Europe (Dressel). It is nearly impossible to say if those amphorae reached "Eastern Celts" region after a very long trip, through the Gallic territories, crossing the German border, potentially going down the Danube until the center of Europe or if they had, more "simply," to climb the Alpine barrier, as a shorter way. In that case, the same outlets do not mean same delivery networks.

Through this region, we can highlight the fact that the choices made by the different Celtic tribes do not match throughout Europe and perfectly reflect the local expectations. The very different pattern drawn in the "Eastern Celts" matrix reflects more than the absence of amphorae in the center of Europe and probably the absence of wine drinking, by extension. It looks like a situation beyond the only problem of the absence of the wine containers. It seems that all the import system is different and based on other choices made by Eastern Celtic tribes, not biased in favor of a Mediterranean wine consumption set.

However, one interesting common point with the other regions is that the diversity of imports refers to the main settlements. The objects occasionally found, like amphorae or ceramic vessels, are only present on the major oppida of the region. This diversity stands out in the case of the major settlements, as was the case of "Saône \& Seine." This particularity, however, is expressed with the opposite imports. It seems like a permanent feature through the entire Celtic world that oppida are, among all types of sites, the most dynamic, the most attractive, and the most capable of attracting imports, both in terms of quantity and diversity.
In the end, the first statement about the diffusion of products in a neighboring area would imply that the further away you move from the exporter area, the more the regions tend to receive the cargo bottom. It would mean that they would possess less numerous and less diversified imports and that the diversity of types of each region would be a subselection of the neighboring region situated closer to the origin of the artifacts. The diffusion of Mediterranean imports appears, however, as far more complex. Even if the most distant regions from the Mediterranean ("England" and "Eastern Celts" areas) are characterized by a lower diversity of categories, the observations presented above obviously highlight regional characteristics. All of them have to be considered as regional compromises between what is possible to obtain (delivery difficulties) and what people choose to possess (specific choices).

The overview of different regional cases enables us to evidence some preferential choices, as regular associations between, on one hand, amphorae, ceramic, and metal vessel inside their own category and, on the other hand, between specific types of amphorae and ceramic vessels and types of amphorae and metal vessels. We have to interrogate these recurrent associations. Is it like a trend for specific Mediterranean products? Or does it more especially answer to particular Celtic needs, filling a gap in a cultural system based on community sharing of alcoholic beverages?

\section{About the Archeological Contributions}

The depiction of European and regional matrices allowed us to point out some interesting associations highlighting cultural, economic, and political choices. Indeed, the specific composition of objects blends, based on the number of their significant copresence inside the Celtic occupations is related to:

- The cargoes made for the deliveries and/or for specific orders;

- either, the modes of utilization or the consumption modes of these products by Celtic populations;

- or, the layouts of the rejections or deposits, once the object has been used.

The matrices we realized allowed us not only to confirm some hypotheses but also to bring to light new aspects. With the state of progress of our research project on Mediterranean imports, we would like to highlight three particular points, which seem to be important for us and the future development of our researches.

\section{Clear Different Imports System in West and East of Europe}

To our knowledge, there is no global map of the Mediterranean imports phenomenon at the European scale. ${ }^{2}$ So, the study we suggest is unique from this point of view.

This scale already allowed us drawing a map showing, in the clearest way, the preferential imports of amphorae in the west of Europe and the total disregard for them in central Europe. It certainly remains the eventual probability that the wine containers were not amphorae, but in a perishable material and thus not found. For now, there is insufficient proof to support

${ }^{2}$ The closest work is certainly the study directed by Olmer et al. (2013). 
this assumption, and archeological analysis cannot be based on absent evidences. In addition, our work on the significance matrices allows us going further with this amphorae presence/ absence difference and enables us to characterize another import system, highlighting the patterns and structures corresponding to particular eastern Celts choices, not similar to the western imports preferences.

In the East of Europe, the preferential import is the metal vessel (biggest effective). There are no evidences for Mediterranean wine import (at large scale). So, we have to suppose that this absence implies chosen drinks from local production. In the ritualized alcoholic beverage consumption field, as during the imported practice of Mediterranean banquet, the values associated with Mediterranean wine import everywhere else in the Celtic world, as richness (wine imports can be bought), power (wine imports can be brought from faraway), or prestige (wine imports can be drunk, given away, even almost squandered) can be considered as rather anecdotal. The fact that there is no wine import implies that richness, power, and/or prestige linked to ritualized consumption are here underestimated but it does not mean that they are absent. They are very probably bound to other imports, to other fields of the everyday life. The hypothesis we can venture is that the prestige carried by wine consumption in the west is replaced, among the Eastern Celts, by other practices, as for example, wearing imported jewelries (73 pieces discovered in the "Eastern Celts" regions, 4 pieces in the 4 other western areas), showcasing the appearance of individuals (in contrast to the ability to hoard in western Europe). This idea must be compared to the discovery contexts of this imports category, notably on funerary sites.

Thus, this eastern system is a completely different approach to the Mediterranean introduction products in the Celtic cultural field, not based on wine consumption prestige as in the west of Europe.

\section{Importation of Goods vs. Importation of the Associated Practices?}

Archeology has definitely provided evidences that populations from the whole Celtic world imported artifacts from the Mediterranean area. Those different categories of goods are now commonly discovered in Latenian context. However, archeology only allows us to approach partially, even sometimes to consider only through assumptions, the way those societies had appropriated those objects. Did they use it according to Mediterranean rules and practices, following the Greek and Roman habits? Did they also import the practices associated with those objects? Or, on the contrary, did the imported artifacts arrive in those faraway lands stripped of all their cultural contents?

The fact that complete sets for wine consumption are most of the time not significantly associated could be seen as a first clue. In Mediterranean traditions, the wine is often consumed during more or less ritualized practices (banquet). They involved several steps: the guest performs the ablutions, and the wine is prepared then it is served. Specific types of metal vessel are used for each of those steps. The absence of this triple service on Latenian contexts may imply that consumption practices were not strictly observed or even known. What mattered may have been to simply impress the most important guests by possessing an amphora to uncork and some imported metal vessel. Furthermore, we evidenced that in most of the cases, the amphorae (and accordingly wine) are not associated with the pieces of metal vessel in which wine should have been consumed, which were rarely imported. Celts may not have cared for the whole Roman ritual of wine preparation and consumption. Without saying that they only looked for drunkenness, the absence of metal vessels associated with wine consumption implies that the Celts used those imports according to their needs and their own value system. The content may have been more important than the container.

Another indication could come from the study of contexts of discovery. We mentioned that "Eastern Belgium" and "England" made a specific use of metal vessel in funerary contexts (Metzler et al., 1991; Carver, 2001).

This association is unique in the La Tène world. In the Mediterranean area, those objects are practical objects for everyday life. They are never placed in the graves to symbolize the wealth or power of the dead. Libations and banquets were generally organized during the funerals next to the grave, but those objects did not accompany the dead into the next world. This difference consists of a genuine change in the use of those artifacts and the message they carry: simple ceramic tableware has its original usage changed to become the content of the dead's viaticum. In this case, the idea of Romanization via the introduction of Mediterranean objects must be balanced. The imported object may have partially lost the symbolical substance it possessed in the cultural area where it came from.

The identification of particular structured imports associations and/or dissociations and the study of their discovery contexts provide some new elements in the understanding of the place Latenian populations gave to those imported objects and their semantics.

\section{Diversity and Effective Factors: Status Markers or Geographical Pressure?}

This study focused specifically on highlighting regional differences to analyze the heterogeneity of the phenomenon across Europe. It is clear, however, that the distribution of Mediterranean imports is not uniform inside those different areas and that the set of imports strongly differs from one site to another. It is not a new point either that Mediterranean imports, as luxury items in the La Tène world, have to be considered as archeological markers of settlements' status (Malrain, 2000; Menez, 2009). Wealth and power can be demonstrated by both quantity (effective of items) and diversity (number of categories and types) of those precious goods. Thus, three groups of region can be created:

- low effective and low diversity: "England" and "Channel coast" regions

- high effective and high diversity: "Saône \& Seine" and "Eastern Belgium" regions

- low effective and high diversity: "Eastern Celts"

The combination "high effective and low diversity" was not observed in the studied areas.

"Saône \& Seine" and "Eastern Belgium" regions are on the most important penetration axis for Mediterranean products, 
and they also are the closest areas from the Roman export zone. We can argue that the geographical proximity factor is one of the most determinants for high effectives and diversity.

In the same way, the "Eastern Celts" region is situated the farthest from the issuing areas. For Bohemia and its neighboring regions, distance may have had an impact on the quantity of items carried to central Europe, obviously not on the diversity (highest number of categories: 9/10).

Both "Channel Coasts" and "England" also are two regions among the most faraway areas from the Mediterranean see, that is why we could suppose that distance and delivery problems may not have given them the possibility of possessing a high effective of imports and that they had to express power with the few they received. We have to keep in mind, however, that amphorae are the most cumbersome and heavy goods imported from Mediterranean. They are, however, the main import discovered in the "Channel Coasts" and "England."

In the end, it seems that geographical pressures (and notably the distance) are one of the key factors in the diffusion of Mediterranean products and have a significant impact notably on the quantity of imported items. However, the concentration of many exogenous goods categories may be identified at status markers on specific types of sites (as fortified urban centers?) able to gather products from different export zones, from different cultural field (consumable goods, vessels, pieces of jewelries, etc.).

In more general terms, the variety of blends from one site to another can manifest in differences in quantities and diversity of imports and in the choice of specific artifacts for specific contexts. Those distinctions can rely on:

- Time, when the three horizons we used are not precise enough to follow the evolution of the imported sets of artifacts;

- Function, for example, when specific types of objects are selected to be placed in the graves;

- Culture, when subregions develop specific selections;

- Proximity to the importer areas and to the main communication axis (land and river routes);

- Status and sites hierarchy, as the studied objects are prestige goods. The richest sites can a priori possess types that are not found in more common settlements.

This theoretical diversity is largely exemplified in our area. The next step will be to determine whether distinctive associations of artifacts may characterize some of the sites, types of sites, subregions, and so on. By combining tools from Network Analysis (exploration of a 2-mode network), formal statistics (Ascending Hierarchical Classification and Factorial Correspondence Analysis), and spatial analysis, we hope to find some coherence in the large heterogeneity of the phenomenon. We hope it would also bring new insights about the organization of the supply network and the several roles all the settlements may have played at different scales in the diffusion of these exogenous goods.

\section{About the Use of Co-presence Matrices and Significance Score}

From the methodological point of view, significance matrices have proven an effective tool for visualizing data, both in terms of diversity and preferential associations. They enable us to quickly highlight crucial features and facilitate their comparisons. The selections we operated involved chronological and regional distinctions, but we could also have used the types of sites, by comparing, for example, the co-presences of objects between funerary sites and settlements in the same area and at the same period.

This tool, however, suffers from one main limitation. The available data from the input table counting the number of objects of each type discovered on each site are not all exploited. The significance matrices are computed from binary presence matrices, disregarding the MNI. More specifically, the matrix considers the discovery of 100 amphorae of type A and 100 ceramic wares of type B similar to the discovery of 100 amphorae of type A and 1 ceramic ware of type B. If this information can be kept when graphically representing the 2 -mode network (sites-objects network) by adding a weight on the edges, the projection into two 1-mode networks is generally associated to an aggregation of those weights into a single value, for instance the average NMI or its median. Finding an appropriate aggregation strategy is a difficult problem.

In the end, co-presences matrices and significance matrices can be valuable tools when used in a complementary way with other methods. For example, distribution maps remain as one of the most used in the study of the spread of artifacts, including Mediterranean imports (e.g., Olmer et al., 2013). They are indeed made for working on geographical phenomena. But this kind of tool does not easily allow the combination of several pieces of information on the same map. A map quickly becomes illegible if we intend to show the spread of various types of artifacts, particularly if one site itself possesses several of them. Co-presence matrices, however, require defining of spatial groups if we want to compare one region to another, but are meant to clearly show regularities in objects associations. Then, co-presence matrices, or even Networks Analysis in general, are to be considered as tools and not an end in themselves. They become valuable when inserted into a set of tools, which offer complementary perspectives on the same phenomenon.

\section{CONCLUSION}

This article was the second step of our research project on the Mediterranean imports. This project started during the summer of 2015, with the creation of the team, the development of the methodology, the data shaping, and the first definitions of the problematic, which were still evolving. The first stage consisted of the project presentation during the network session of the European Archeological Association annual meeting in Glasgow (September 2-5, 2015), which is published in this volume.

This unusual project benefits from an unpublished corpus of data, an ambitious scale of work and a methodology never tested on such objects as it has dealt with. As in all new approaches, we still face unexpected problems and difficulties from day to day. We had to domesticate a large amount of data, which was not created for our type of analysis. We also had to create our own tools, as typological organizations, chronological divisions, and a way to calculate the significance of the observed associations 
on the co-presence matrices. This is a standard procedure for an exploratory approach. All this preparation time and those methodological trials and errors were of course time consuming but also instructive for our unprecedented process. We are now capable of identifying methodological problems, notably due to the quality of the data (heterogeneous corpus, chronological imprecision, etc.), and we are on the track to solve them or at least to lower their influence on the results.

The matrices, created for this article, are already highly instructive and provide a major step forward in the project course. The methodology we used and the matrices we drew allow us to obtain consistent results in preferential associations between imported objects and set the stage for a better understanding of the economic and even political and social uses of these Mediterranean products in the Celtic world.

We would of course like to be able to pursue this project in months and years to come. The next priority step is to work on the occupations. Indeed, to improve these first results and to go into the hypothesis in depth, we will have to group sites according to their preferential associations to gather groups of sites constituted on the similarity of the diversity and quantity of their objects. We also plan to combine other statistical and cartographic methods,

\section{REFERENCES}

Arcelin, P., and Brunaux, J.-L. (2003). Cultes et sanctuaires en France à lâge du Fer. Paris: CNRS; Gallia. 60.

Baray, L. (2014). Les mercenaires celtes et la culture de La Tène: Critères archéologiques et positions sociologiques. Dijon: Editions universitaires de Dijon. $139-62$.

Barral, P. (2012). Regards sur la chronologie de la fin de lâge du Fer (IIIe - Ier siècle avant J.-C.) en Gaule non méditerranéenne, actes de la table ronde tenue à Bibracte, Glux-en-Glenne, 15-17 octobre 2007. Glux-en-Glenne: Centre archéologique européen.

Bertin, J. (1967). Sémiologie graphique: Les diagrammes - Les réseaux - Les cartes. Paris: Editions de l'Ecole des Hautes Etudes en Sciences.

Brughmans, T. (2010). Connecting the dots: towards archaeological network analysis. Oxford Journal of Archaeology 29: 277-303. doi:10.1111/j.14680092.2010.00349.x

Brun, P. (1993). "La complexification sociale en Europe moyenne pendant lâge du Fer: essai de modélisation," in Fonctionnement social de l'âge du Fer: opérateurs et hypothèses pour la France, Actes de la Table ronde de Lons-le-Saunier, October 24-26, 1990 (Lons-le-Saunier: Cercle Girardot), 275-290.

Brun, P. (in press). L'archéologie des inégalités et de l'État en Europe.

Carver, E. (2001). The Visibility of Imported Wine and Its Associated Accoutrements in Later Iron Age Britain. Oxford: Achaeopress. BAR British Series. 325.

Clarke, D.L. (1962). Matrix analysis and archaeology with particular reference to British beaker pottery. Proceedings of the Prehistoric Society 28: 371-82. doi:10.1017/S0079497X00015772

Collis, J. (1984). Oppida: Earliest Towns North of the Alps. Sheffield: University of Sheffield (Dept. of Prehistory and Archaeology).

Čučković, Z. (2015). Exploring intervisibility networks: a case study from Bronze and Iron age Istria (Croatia and Slovenia). In CAA2014: 21st Century Archaeology: Concepts, Methods and Tools: Proceedings of the 42nd Annual Conference on Computer Applications and Quantitative Methods in Archaeology, Edited by F. Giligny, F. Djindjian, L. Costa, P. Moscati, and S. Robert, (Oxford: Archaeopress Archaeology), 469-478.

Cunliffe, B. (1993). La Gaule et ses voisins: Le grand commerce dans l'Antiquité. Paris: Picard.

Djindjan, F. (1991). Méthodes pour larchéologie. Paris: A. Colin, 1-5.

Fabrikant, S. I, Montello, D.R., Ruocco, M., and Middleton, R.S. (2004). The distance-similarity metaphor in network-display spatializations. Cartography such as classical distribution maps, spatial analysis, Ascending Hierarchical Classification, or classifications methods from networks analysis. The current task is the setting up of a Latent Block Model (LBM). It is applied on a bipartite network between some sites toward some objects, to suggest broad clusters of sites on the one hand and objects on the other hand. This probabilistic approach relies on the intensity of the links between sites and objects. For instance, different sites where significant amounts of the same artifact are found will likely be clustered together. In other words, the LBM would allow to link sites groups to specific sets of imported artifacts, taking into account the MNI. It would help to suggest to which extent particular associations of artifacts can be specific to some contexts.

In the end, this innovative work, still in progress, should provide new material for a better understanding of the complexity of the commercial relationships between Mediterranean and Celtic worlds at the end of the La Tène period.

\section{AUTHOR CONTRIBUTIONS}

AF: data gathering, issues, analysis, interpretations, and writing. $\mathrm{CF}$ and FR: issues, analysis, interpretations, and writing.

and Geographic Information Science 31: 237-52. doi:10.1559/1523040042 742402

Fichtl, S. (2000). La ville celtique: les "oppida" de 150 av. J.-C. à 15 apr. J.-C. Paris: Errance.

Ghoniem, M., Fekete, J.-D., and Castagliola, P. (2005). Readability of graphs using node-link and matrix-based representations: controlled experiment and statistical analysis. Information Visualization Journal 4: 114-35. doi:10.1057/ palgrave.ivs.9500092

Graham, S. (2006). Networks, agent-based models and the Antonine itineraries: implications for Roman archaeology. Journal of Mediterranean Archaeology 19: 45-64. doi:10.1558/jmea.2006.19.1.45

Gruel, K. (1989). La monnaie chez les Gaulois. Paris: Errance.

Henry, N., and Fekete, J.-D. (2006). MatrixExplorer: a dual-representation system to explore social networks. IEEE Transactions on Visualization and Computer Graphics 12: 677-84. doi:10.1109/TVCG.2006.160

Husi, P. (2001). Quantification et datation en céramologie (Le nombre minimum d'individus: la technique de quantification la mieux adaptée à la datation des contextes archéologiques à partir de l'exemple de Tours). Les petits cahiers d'Anatole 6: 1-27.

Jennings, B. (2016). Exploring late bronze age systems of bronzework production in Switzerland through network science. Science and Technology of Archaeological Research 2: 90-112. doi:10.1080/20548923.2016.1183940

Malrain, F. (2000). Fonctionnement et hiérarchies des fermes dans la société gauloise du IIIème siècle à la période romaine: l'apport des sites de la moyenne vallée de l'Oise. Paris: Paris 1 - Panthéon-Sorbonne.

Malrain, F., Matterne, V., and Méniel, P. (2002). Les paysans gaulois, IIIe siècle-52 av. J.-C. Paris: Errance.

Matterne, V. (2001). Agriculture et alimentation végétale durant lâge du Fer et lépoque gallo-romaine en France septentrionale. Montagnac: M. Mergoil. Archéologie des plantes et des animaux 1.

Menez, Y. (2009). Le Camp de Saint Symphorien à Paule (Côtes d'Armor) et les résidences de l'aristocratie du Second âge du Fer en France septentrionale. Paris: Paris 1 - Panthéon-Sorbonne.

Mercklé, P. (2004). La sociologie des réseaux sociaux. Paris: Découverte.

Metzler, J., Waringo, R., Bis, R., and Metzler-Zens, N. (1991). Clémency et les tombes l'aristocratie en Gaule Belgique. Luxembourg: Musée national d'Histoire et d'Art. Dossiers d'archéologie du Musée national d'Histoire et d'Art I.

Nakoinz, O. (2013). Archäologische Kulturgeographie der ältereisenzeitlichen Zentralorte Südwestdeutschlands. Bonn: Habelt. 
Olmer, F., Girard, B., Verrier, G., and Bohbot, H. (2013). « Voies, acteurs et modalités du grand commerce en Europe occidentale ». In L'Âge du Fer en Aquitaine et sur ses marges. Mobilité des hommes, diffusion des idées, circulation des biens dans l'espace européen à l'Âge du Fer, Vol. 30, Edited by A. Colin and F. Verdin, 665-691. Bordeaux: Aquitania.

Östborn, P., and Gerding, H. (2014). Network analysis of archaeological data: a systematic approach. Journal of Archaeological Science 49: 75-88.

Östborn, P., and Gerding, H. (2015). The diffusion of fired bricks in Hellenistic Europe: a similarity network analysis. Journal of Archaeological Method and Theory 22: 306-44. doi:10.1007/s10816-014-9229-4

Poux, M. (2004). Lâge du vin. Rites de boisson, festins et libations en Gaule indépendante. Montagnac: Monique Mergoil. Protohistoire européenne 8.

Picon, M., and Ricq de Boüard, M. (1989). Aires de production des grécoitaliques et des Dr. 1. 3 - Étude en laboratoire. In Amphores romaines et histoire économique: dix ans de recherche, Actes du Colloque de Sienne, 22-24 mai 1986, 35-65. Palais Farnèse (Rome): École Française de Rome, 1989. (Collection de l'École Française de Rome; $\left.\mathrm{n}^{\circ} 114\right)$.

Pierrevelcin, G. (2012). Les relations entre la Bohême et la Gaule du IVe au Ier siècle avant J.-C., Dissertationes Archaeologicae Brunenses/Pragensesque, 12, Filozofická fakulta Univerzity Karlovy v Praze, Prague.

Rossi, F., Villa-Vialaneix, N., and Hautefeuille, F. (2014). Exploration of a large database of French notarial acts with social network methods. Digital Medievalist 9 .

Roymans, N. (1990). Tribal Societies in Northern Gaul: An Anthropological Perspective. Amsterdam: Universiteit van Amsterdam. Cingula 12.

Sindbaek, S. (2007a). Networks and nodal points: the emergence of towns in early Viking age Scandinavia. Antiquity 81: 119-32. doi:10.1017/S0003598X 00094886
Sindbaek, S. (2007b). The small world of the Vikings: networks in early medieval communication and exchange. Norwegian Archaeological Review 40: 59-74. doi:10.1080/00293650701327619

Sindbaek, S. (2012). Viking disruptions or growing integration? Contextualising communication networks in the 10th century North Sea. In Raumbildung durch Netzwerke? Der Ostseeraum zwischen Wikingerzeit und Spätmittelalter aus archäologischer und geschichtswissenschaftlicher Perspektive, Edited by S. Kleingärtner and G. Zeilinger, 19-38. Bonn: Dr. rudolf habelt gmbh.

Sindbaek, S. (2013). Broken links and black boxes: material affiliations and contextual network synthesis in the Viking world. In Network Analysis in Archaeology: New Approaches to Regional Interaction, Edited by C. Knappett, 71-94. Oxford: Oxford University Press.

Tabourier, L., Roth, C., and Cointet, J.-P. (2011). Generating constrained random graphs using multiple edge switches. Journal of Experimental Algorithmics 16: doi:10.1145/1963190.2063515

Tugby, D.J. (1958). A typological analysis of axes and choppers from southeast Australia. American Antiquity 24: 24-33. doi:10.2307/276738

Conflict of Interest Statement: The authors declare that the research was conducted in the absence of any commercial or financial relationships that could be construed as a potential conflict of interest.

Copyright (C) 2017 Feugnet, Rossi and Filet. This is an open-access article distributed under the terms of the Creative Commons Attribution License (CC BY). The use, distribution or reproduction in other forums is permitted, provided the original author(s) or licensor are credited and that the original publication in this journal is cited, in accordance with accepted academic practice. No use, distribution or reproduction is permitted which does not comply with these terms. 


\section{APPENDIX}

\section{A. Calculating and Representing Significance Matrices}

The score is based on the calculation of co-presences that could be observed under a random assignment model in which objects would be associated with sites at random, while preserving site diversities and object popularity. The rationale is to take into account differences between rare and frequent objects on the one hand, and between sites with high or low diversities of objects on the other hand, while removing the dependencies between sites and objects. Technically, this amounts to generating simulated binary data tables with marginal counts identical to the true data table.

Let us consider again the simple artificial example from Figure 3 with six sites and four objects. The presence matrix (without counts) is:

\begin{tabular}{lcccc}
\hline SitelObject & Object 1 & Object 2 & Object 3 & Object 4 \\
\hline Site A & 1 & 1 & 0 & 0 \\
Site B & 1 & 1 & 0 & 0 \\
Site C & 0 & 0 & 1 & 0 \\
Site D & 0 & 0 & 1 & 1 \\
Site E & 0 & 1 & 1 & 1 \\
Site F & 0 & 0 & 1 & 1
\end{tabular}

Random versions of this table are obtained by choosing randomly where to put the ones and the zeros under the constraints that the number of distinct object types observed at each site remain constant and that the number of sites in which an object type is found remains also constant. In other words, row and column sums must be kept equal to the initial one. In the example above, this means, for instance, that the column of Object 2 is constrained to contain 3 ones and 3 zeros. Similarly, the row of Site E must contain 3 ones and 1 zero. An example of such a random matrix is the following one:

\begin{tabular}{lcccc}
\hline SitelObject & Object 1 & Object 2 & Object 3 & Object 4 \\
\hline Site A & 0 & 0 & 1 & 1 \\
Site B & 0 & 1 & 1 & 0 \\
Site C & 0 & 0 & 0 & 1 \\
Site D & 1 & 0 & 1 & 0 \\
Site E & 1 & 1 & 1 & 0 \\
Site F & 0 & 1 & 0 & 1 \\
\hline
\end{tabular}

Notice that in the original matrix, Objects 3 and 4 were copresent in three sites while they are only co-present on one site in the random matrix. Another possible random matrix is:

\begin{tabular}{lcccc}
\hline SitelObject & Object 1 & Object 2 & Object 3 & Object 4 \\
\hline Site A & 1 & 0 & 1 & 0 \\
Site B & 0 & 1 & 0 & 1 \\
Site C & 0 & 1 & 0 & 0 \\
Site D & 1 & 0 & 1 & 0 \\
Site E & 0 & 1 & 1 & 1 \\
Site F & 0 & 0 & 1 & 1
\end{tabular}

In this case, Objects 3 and 4 are co-present on two sites.

As shown on Figure 4, the co-presence matrix associated with the observed data is then:

\begin{tabular}{lcccc}
\hline Co-presence & Object 1 & Object 2 & Object 3 & Object 4 \\
\hline Object 1 & NA & 2 & 0 & 0 \\
Object 2 & 2 & NA & 1 & 1 \\
Object 3 & 0 & 1 & NA & 3 \\
Object 4 & 0 & 1 & 3 & NA \\
\hline
\end{tabular}

According to this co-presence matrix, the association between Object 3 and Object 4 seems to be strong, while the association between Object 2 and Object 3 seems to be weak. In the two random matrices, Object 3 and Object 4 were co-present on one or two sites, thus being co-present on three sites might still be considered significant. On the contrary Object 2 and Object 3 were co-present on one or two sites, a thus being co-present on one site might happen by chance. Notice, however, that using only two random matrices is far from being sufficient, as detailed below.

In general, the random binary matrices are generated by a switching mechanism. One selects randomly two pairs of associated objects and sites (for instance, Site 1 and Object 1 as the first pair and Site 3 and Object 3 as the second one, in the above example). Then, the associations are swapped: the object of the first pair is now associated with the site of the second pair and vice versa. The process is repeated a sufficient number of time to produce a random table. This is a particular case of edge switching in networks (Tabourier et al., 2011).

Given the simulated tables/networks, co-presences are computed as on the original data. For each pair of objects, we obtain this way a collection of numbers of sites of co-presence. Then, the true number is ranked among this collection. A small rank indicates that the number of sites on which the pair of objects are co-present is significantly smaller than expected under the random model: this means that when one of the object is present in a site, the other is specifically not present. A high rank indicates on the contrary that the number of sites on which the pair of objects are co-present is significantly larger than the expected number under the random model: this means that when one of the object is present in a site, the other is also present. In order for the ranks to be significant, we generated for the real data 1,000 random matrices.

Let us consider a few cases extracted from the example above. As the example is very simple, we can generate 10,000 random matrices (rather than 1,000 in the real data case). The distribution of the co-presences of Object 3 and Object 4 is given by the following table:

\begin{tabular}{lccc}
\hline Number of sites of co-presence & 1 & 2 & 3 \\
Number of random instances & 3,779 & 5,449 & 772
\end{tabular}

The table shows that out of 10,000 random matrices, 772 are such that Object 3 and Object 4 are co-present on 3 sites. Therefore, this co-presence level happens by chance in almost $8 \%$ of the case and should not be considered significant. In fact, 
in this particular example, none of the co-presence levels are significant. This is mostly a consequence of using a very small and simple presence matrix. In the real data, significant values occur frequently. For instance at the middle horizon, Italic amphorae and Campana ceramic vessels are co-present on 34 sites, while the highest number of sites in which they are co-present in random matrices is 31 . Thus, the association is highly significant, a shown in Figure 6 and discussed in the text.

In order to visualise the ranks, a colour code is used. Low ranks are encoded in the matrix visualisation by blue tones, while high ranks use red tones. Central ranks correspond to typical values and to non significant co-presences, which is to co-presences that can be explained by chance. They are represented by a unique grey tone. We use seven colours, the unique grey tone, three blues and three reds. The red levels correspond to significance levels of $5,2.5$, and $0.5 \%$. Thus, when a co-presence is displayed with the strongest red tone, the corresponding number of sites of copresence is reached in the random matrices at most in $0.5 \%$ cases (5 matrices out of 1,000). The blue levels are identical.

\section{B. List of Imports}

Alphabet
6000
6001
6002
6003
Amphorae
6004
6005
6006
Weapons
6007
Ceramic
6008
6009
6010
6011
6012
6013

$\begin{array}{ll}\text { Greek Alphabet } & 6034 \\ \text { Undetermined Alphabet } & 6035 \\ \text { Latin Alphabet } & 6036 \\ \text { Mixed Alphabet } & 6037 \\ & 6038 \\ \text { Other Amphora } & 6039 \\ \text { Iberian Amphora } & 6040 \\ \text { Italic Amphora } & 6041 \\ & 6042 \\ \text { Weapon } & 6043 \\ & 6044 \\ \text { Ampurian Ceramic } & 6045 \\ \text { Other Ceramic } & 6046 \\ \text { Campana Ceramic } & 6047 \\ \text { Common Ceramic } & 6048 \\ \text { Undetermined Ceramic } & 6049\end{array}$

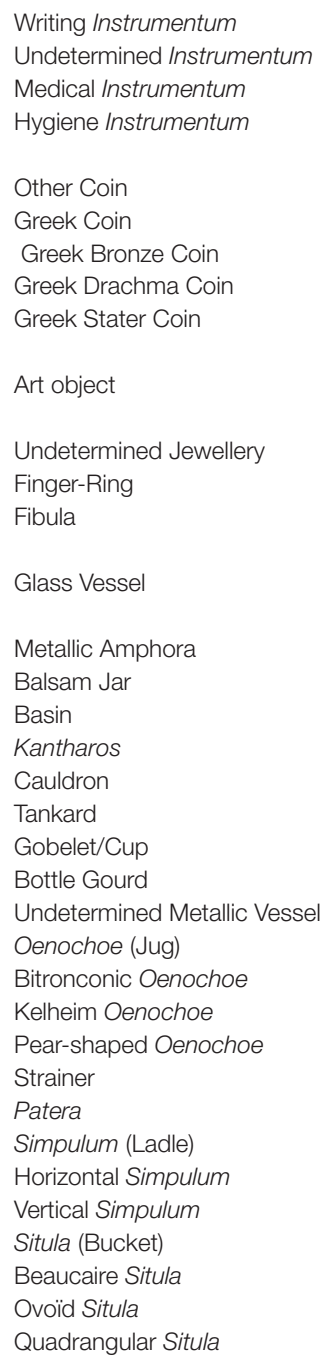

